\title{
Sağlık Hizmetlerinde Nesnelerin İnterneti Uygulamalarının Bibliyometrik Analizi
}

\author{
Gizem Köse $^{1 *}$, Mehmet Nurullah Kurutkan ${ }^{2}$ \\ 1* Düzce Üniversitesi Sosyal Bilimler Enstitüsü Sağlık Yönetimi Anabilim Dalı, Düzce, Türkiye (ORCID: 0000-0002-2985-3299), kosegizem12@,gmail.com \\ ${ }^{2}$ Düzce Üniversitesi I̦şletme Fakültesi Sağlık Yönetimi Bölümü, Düzce, Türkiye (ORCID: 0000-0002-3740-4231), nurullahkurutkan@duzce.edu.tr
}

(İlk Geliş Tarihi 19 Mart 2021 ve Kabul Tarihi 06 Eylül 2021)

(DOI: 10.31590 /ejosat.868000)

ATIF/REFERENCE: Köse, G. \& Kurutkan, M.N. (2021). Sağlık Hizmetlerinde Nesnelerin İnterneti Uygulamalarının Bibliyometrik Analizi. Avrupa Bilim ve Teknoloji Dergisi, (27), 412-432

Öz

Bu çalışmanın amacı, sağlık hizmetlerinde Nesnelerin İnterneti (IoT) uygulamalarını ele alan bilimsel yayınların araştırma eğilimlerini incelemektir. Bu bağlamda Web of Science veritabanında 2001-2019 yılları arasında yer alan İngilizce makalelerin R programlama dili kullanılarak bibliyometrik analizi yapılmıştır. Bibliyometrik analizde, R programının web arayüzü olan Biblioshiny kullanılmıştır. Yayınlar kategorize edilerek türleri, yıllara göre eğilimleri incelenmiş; ülkelerine, kurumlarına ve yazarlarına göre değerlendirilmiştir. Bulgular, en çok atıf alan çalışmalar ışığında tartışıldı. Bu çalışma sağlık alanında IoT uygulamalarının güncel konularını sunmak ve araştırma eğilimlerini incelemek için önemli bir kaynak niteliğindedir.

Anahtar Kelimeler: Bibliyometrik analiz, Nesnelerin İnterneti, Sağlık hizmetleri.

\section{Bibliometric Analysis of Internet of Things Applications in Healthcare Services}

\begin{abstract}
This study aims to examine the research trends of scientific publications dealing with Internet of Things (IoT) applications in healthcare. In this context, a bibliometric analysis of English articles in the Web of Science database between 2001-2019 was performed using the $\mathrm{R}$ programming language. In the bibliometric analysis, Biblioshiny (web interface of $\mathrm{R}$ program) was used. Publications were categorized their types and trends over the years were examined, it has been evaluated according to their countries', institutions' and authors'. Findings were discussed in the light of the most cited studies. This study is an important resource to present current issues of IoT applications in healthcare and to examine research trends.
\end{abstract}

Keywords: Bibliometric analysis, Internet of Things, Healthcare.

\footnotetext{
*Sorumlu Yazar: kosegizem12@gmail.com
} 


\section{Giriş}

Bilgi teknolojisinin gelişmesiyle birlikte, akıllı sağlık kavramı yavaş yavaş ön plana çıkmıştır. Akıllı sağlık hizmeti, geleneksel tıbbi sistemi çok yönlü bir şekilde dönüştürerek sağlık hizmet sunumunu daha verimli, daha rahat hale getirmek için loT, büyük veri, bulut bilişim ve yapay zeka gibi yeni nesil bilgi teknolojilerini kullanır (Tian vd., 2019). Nesnelerin İnterneti akıllı servislerin son kullanıcılara götürüldüğü bir ortam sağlamak üzere entegre ve birlikte çalışan sensörler, ağ ve işleme teknolojileriyle donatılmış akıllı nesneler içeren bir ekosistem olarak kabul edilir. IoT yer ve zaman bağımsız, insan yaşamındaki her aktivitede kullanılmak amacıyla sınırsız fayda sağlayan akıllı hizmetlerdir. Tüm bu imkan ve hizmetlerin gerçekleştirilebilmesi için, IoT ortamında çeşitli uygulamalar yoluyla veri iletimi sağlanır (Asghari, Rahmani, \& Javadi, 2019). Bu uygulamaların en çok kullanıldığı alanlardan biri de sağlık alanıdır. Sağlık hizmetlerinde IoT uygulamalarının arkasındaki temel fikir herhangi bir kisitlama olmadan hastaya ait verilerin algılanabilmesi, işlenebilmesi ve akıllı cihazlar ile uzaktan iletişimin sağlanabilmesidir (Bhatt \& Bhatt, 2017). Akıllı sağlık bireyler perspektifinden değerlendirildiğinde bireyler için daha iyi sağlık öz yönetiminin gerçekleşmesini ve tıbbi hizmetlerin içeriğinin kişiselleşmesini sağlayabilir. Tibbi kurumlar perspektifinden değerlendirildiğinde ise maliyetleri azaltarak hastanın tıbbi deneyimini iyileştirebilir. Araştırma kurumları için akıllı sağlık hizmeti, araştırma maliyetini ve süresini azaltarak araştırmanın genel verimliliğini artırabilir (Xiang, Zeng, \& Shen, 2016). Yapılan bir çalışmada 2025 yılına kadar IoT uygulamalarının pazar payının \%41'ini sağlık hizmetlerinin oluşturacağı ifade edilmiştir (Al-Fuqaha, Guizani, Mohammadi, Aledhari, \& Ayyash, 2015; Manyika vd., 2013).

Sağlık hizmetlerinde IoT uygulamaları literatürü incelendiğinde araştırmaların sağlıkta nesnelerin interneti (Yin, Zeng, Chen, \& Fan, 2016), IoT'nin kişisel sağlık hizmetleri üzerindeki etkileri ve uygulamaları (P. Yang, Qi, Min, \& Xu, 2017), giyilebilir teknolojiler (Castillejo, Martinez, Rodriguez Molina, \& Cuerva, 2013), sağlık alanında IoT'nin firsatları ve zorlukları (Baker, Xiang, \& Atkinson, 2017), evde sağlık hizmetleri (Pang vd., 2015), büyük veri (Dimitrov, 2016), bulut sistemleri (Hossain \& Muhammad, 2016), akıllı sağlık sistemleri (Rahmani vd., 2018), bulut teknolojisi (Abawajy \& Hassan, 2017), verilerin gizliliği ve güvenliği (Yang Yang, Zheng, Guo, Liu, \& Chang, 2019) gibi alanlarda yapıldığı görülmektedir. Ayrıca konu hakkında sistematik literatür çalışması yapılmış ve çalışmada son 10 yılda yayınlanan 5000'den fazla makale değerlendirilerek kişisel sağlık kayıtları sınıflandırılmış; konunun zorlukları, sorunları ve ilgili standartları ile ana profilleri belirlenmiştir (Roehrs, da Costa, Righi, \& Farias de Oliveira, 2017). Görüldüğü üzere alan oldukça geniş ve derinlemesine araştırmaların yer aldığı bir alandır. Bu durumda alanı nicel ve istatistiksel açıdan değerlendirmek için bibliyometri en uygun yöntemlerden biri olacaktır.

Bibliyometri enformasyon alanında kullanılmaktadır ve bibliyometrik yöntemler sayesinde araştırmaların belli bir yönü ve değeri ortaya çıkarılabilmektedir (Rodriquez-Soler, UribeToril, \& Valencio, 2020; Shang, Saladin, Fry, \& Donohue, 2015). Meta verilere dayanan bibliyometrik analizin (Pernitez-Agan, Bautistia, Lopez, Sampson, \& Wickramage, 2020) sosyal bilimlerde kullanımı araştırmanın nesnelliğini artırmakta ve farklı yazarların bakış açısının biraraya getirilmesini sağlamaktadır (Zupic \& Cater, 2014).

Yaygın bir şekilde bibliyometrik analizler iki amaca hizmet etmektedir (Kurutkan ve Orhan, 2018a: 9-10). Bunlar da 1) geleneksel bibliyometrik parametreler açısından bibliyometri ve 2) modern anlamda bilim haritalama tekniklerini kullanan ücretli ve ücretsiz yazılımlar açısından bibliyometri şeklindedir. Geleneksel yöntemde genellikle en terimi iş görmekte ve bu bağlamda da konu ile ilgili en'ler (yazarlar, dokümanlar, ülkeler, dergiler vb.) ön plana çıkarılmaktadır. Bu kapsamda ya herhangi bir veri tabanı (Web of Science, Scopus, Pubmed vb.) üzerinden konunun önde gelen unsurları incelenir veya bir yazılım aracılığı ile gerçekleştirilir (Kurutkan ve Orhan, 2018b: 2-3). Modern yöntemde ise birçok ücretli veya ücretsiz yazılım programı kullanılabilmektedir. Bu kapsamda ücretsiz hizmet veren SciMAT (Cobo vd., 2012), Citespace (Chen, 2014), HistCite (Bankar, 2019), BibExcel (Persson, Danell ve Schneider, 2009), Gephi (Bastian, 2009), Voswiever (Van Eck ve Waltman, 2013), gibi birçok yazılım bibliyometride karar almayı ve görselleştirmeyi hızlandırmaktadır.

Herhangi bir çalışma alanındaki mevcut literatürün miktarı karşısında, çoğu zaman araştırmacılar, mevcut bilgi birikiminin büyüklüğü karşısında, kendisini çaresiz ve hatta yetersiz hissedebilmektedir. Bu sorunu çözebilecek ve çok kısa bir zaman diliminde en etkin okuma düzeyine ulaştıracak tekniklerden birisi de bibliyometrik analizdir. Nesnelerin interneti konusunun sağlık disiplini özelinde bibliyometrik tekniklerle incelenmesi bu çalışmanın temel amacını oluşturmaktadır.

Nesnelerin İnterneti kavramı hem bütün endüstriler (bu ayırıma genel bakış diyeceğiz) açısından hem de sektörel açıdan bibliyometrik analizlere tabi tutulmuştur. Genel bakış tekniği ile inceleyen çalışmada (Mishra ve ark, 2016) performans (citation ve pagerank analizleri gibi) analizleri yapmışlardır. Genel bakışı sadece bir coğrafi bölgenin (Arap coğrafyası) çalışmalarına ayıranlar da (Kaba ve Ramaiah, 2019) bulunmaktadır. Ayrıca veri madenciliği tekniği ile 778 makaleyi inceleyen çalışmalar da bulunmaktadır (Konstantinidis, ve ark. 2017). Özel konular bağlamında ve sektörel uygulamalar bağlamında inceleyen çok sayıda çalışma bulunmaktadır. Nesnelerin interneti kavramını, sirkuler ekonomi (Nobre ve Tavares, 2017), patent sayıları (Li, Pak ve Bi, 2020), gida endüstrisi (Bouzembrak ve ark. 2019), pazarlama disiplini (Miskiewicz, 2020), blockchain teknolojisi (Kamran ve ark. 2020), ilgili teknolojinin önündeki zorluklar ve engeller (Dadkhah ve ark. 2020) ve sadece sosyal bilimlerin bakış açısı (Leong, Tajudeen ve Yeong, 2021) ile inceleyen çalışmalar ön plana çıkmaktadır. Sağlık açısından inceleyen sadece bir çalışma bulunmaktadır. O da sağlık trendleri (Konstantinidis ve ark. 2017) bağlamında incelemiştir.

Yukarıdaki çalışmalar incelendiğinde sağlık sektörünün tamamını 2020 yılına kadar yayınlanan çalışmalar açısından inceleyen bir çalışma tespit edilememiştir. $\mathrm{Bu}$ çalışma ilgili boşluğu doldurmak amacı ile tasarlanmıştır.

Yukardaki amaca ulaşabilmek için genel bir literatür değerlendirilmesi yapılmış, çalışmanın amacı netleştirilmiştir. Bundan sonraki bölümlerde arama stratejisi ve seçilen veri tabanlarından bahsedilecektir. Hangi analizlerin yapıldığ 1 tablolaştırılmış ve bulgular tablodaki sıraya riayet edilrek yorumlanmıştır. Tartışma kısmında elde edilen bulgular analiz edilmiş ve sonuç ve önerilerde bulunulmuştur. 


\section{Materyal ve Metot}

\subsection{Materyal}

Çalışmanın veri setini oluşturan makaleler Web of Science Core Collection veri tabanından elde edilmiştir. Arama yapılırken AND ve OR bağlaçları kullanılmış; makale başlığında konunun sağlık disiplini olmasını sağlayan anahtar kelimeler seçilmiştir. Sağlık hizmetlerinini temsil eden kelimeler makale başlığında aratılmış ve elde edilen sonuçlar içinde (AND bağlacı burada kullanılmıştır) nesnelerin interneti kavramı aratılarak konu netleştirilmiştir. Makale başlığ 1 düzeyinde "health", "health care", "healthcare", "health-care", "healthcare management", "health care management", "health-care management", "health service", "healthcare service", "health care service", "health-care service", "primary care", "hospital", "clinical", "pharmacy", "clinics" arama kelimeleri OR bağlacı kullanılarak aratılmıştır. Bu sayede sağlık hizmetleri alanını içeren çalışmaların tamamına ulaşılmaya çalışılmıştır. Aramanın bir diğer kısıtını ise zaman dilimi ve endeksler oluşturmaktadır. Bu kapsamda 1975-2019 y1lları arasında yayınlanan makaleler veri setine dahil edilmiştir. Arama neticesinde konu ile alakalı ilk makalenin 2001 yılında yayınlandığı görülmüştür. Bu sebeple analizde 2001 ile 2019 yılları arasında yer alan çalışmalar değerlendirilmiştir. Endeksler arasından ise SCI-EXPANDED ve SSCI ile endekslenen makaleler seçilerek arama yapılmıştır. Elde edilen sonuçlarda "internet of things" konusu AND bağlacı ile süzülerek tekrar arama yapılmıştır. Bu sayede sağlık hizmetlerini ve nesnelerin internetini birlikte konu edinen çalışmalara erişilmiştir. Doküman tipi olarak Article ve Review türündeki çalışmalar, dil olarak ise İngilizce dilinde yayınlanan çalışmalar kapsama alınmıştır. Şekil 1 'de veri setinin elde edilmesi süreci görselleştirilmiştir.

\section{Şekil 1. Veri Setinin Elde Ediliş Süreci (Çalışma Ă̆acı)}

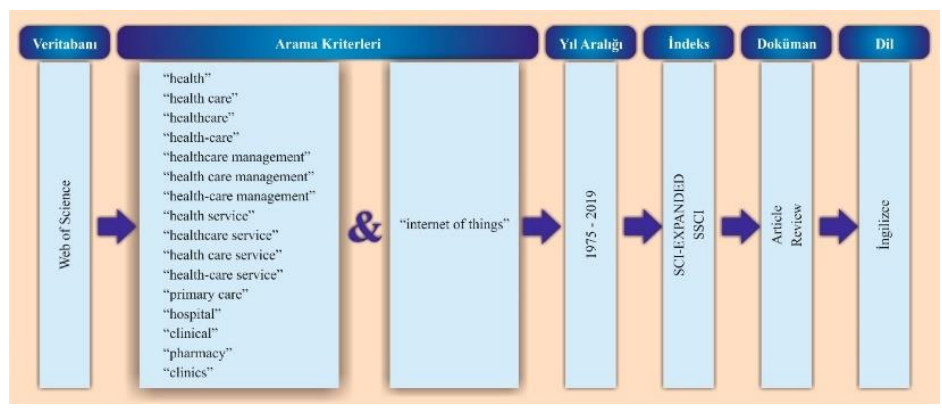

\subsection{Metot}

1960 yıllarında John Chambers ve arkadaşları tarafından temeli atılan $\mathrm{R}$ programlama dili istatistiksel hesaplamalarda kullanılan bir araçtır (European Environment Agency, 2020; Prajapati, 2013). R, S diline dayanmaktadır ve bu da kullanıcıların yapılan algoritmik seçimleri takip etmesini kolaylaştırır. İleri düzey kullanıcılar, $\mathrm{R}$ nesnelerini doğrudan işlemek için $\mathrm{C}$ kodu yazabilir. R, veri işleme, hesaplama ve görselleştirme için entegre bir yazılım paketidir ve etkili bir veri işleme ve depolama tesisi içermektedir. Verilerin grafiklerle ifade edilmesini sağlayan olanaklar iyi geliştirilmiştir, basit ve etkili bir programlama dilidir (The R Foundation, 2020). Bu makalede yazılım olarak R tabanlı bir kütüphane olan "bibliometrix" ve kullanıcı dostu olan ve "bibliometrix'in" web tabanlı arayüzü olan "biblioshiny" kullanılmıştır. Açık yazılım niteliğine sahip olan Bibliometrix, esnektir, hızla yükseltilebilir ve diğer istatistiksel R paketleri ile entegre edilebilir. Bu nedenle, bibliyometri gibi sürekli değişen bir bilim disiplininde oldukça kullanışlıdır. Bibliometrix tüm temel bibliyometrik analizyöntemlerini içermektedir ancak özellikle bilim haritalama için kullanılmaktadır (Aria ve Cuccurullo, 2017). İlgili yazılımın seçilmesinde kullanıcı dostu olması ve analiz aşamaları takip edildiğinde bir makale için gerekli olan bilgi gövdesinin daha rahat inşa edilebilmesidir.

Kısıtlamalar neticesinde 519 makaleye erişilmiş ve bu makaleler plain text formatında indirilmiştir. Makaleler arasında erken erişimli olanlar hariç tutularak 503 adet makalenin bibliyometrik analizi R 4.0.3 paket programı aracılığı ile yapılmıştır. Bibliyometrik analiz dahilinde indirilen makalelerin veri seti, kaynaklar, yazarlar ve dokümanlar gibi birimleri incelenmiştir. İncelemeler çalışmanın bulgular kısmında detaylı bir biçimde açıklanmaktadır. Analiz birimleri ve analiz türleri Tablo 1'de gösterildiği gibidir.

Tablo 1. Bu çalışmada kullanılacak Analiz Birimi ve Alt Bileşenleri (Analiz Türü)

\begin{tabular}{|c|c|}
\hline Analiz Birimi & Analiz Türü \\
\hline Veri Seti & $\begin{array}{l}\text { Veri Seti Hakkında Temel Bilgiler } \\
\text { Y1lık Bilimsel Üretim } \\
\text { Y1llık Ortalama Atıf Sayısı }\end{array}$ \\
\hline Kaynaklar & $\begin{array}{l}\text { En İlgili Dergiler } \\
\text { Bradford Yasası } \\
\text { Kaynak Etkisi } \\
\text { Kaynak Dinamikleri }\end{array}$ \\
\hline Yazarlar & $\begin{array}{l}\text { En Alakalı Yazarlar } \\
\text { En Çok Yerel Atıf Alan Yazarlar } \\
\text { Yazarların Zaman İçindeki } \\
\text { Lotka Yasası } \\
\text { Yazar Etkisi } \\
\text { En İlgili Bağlantılar } \\
\text { Sorumlu Yazarın Ülkesi } \\
\text { Ülkelerin Bilim Üretimi } \\
\text { En Çok Alıntı Yapılan Ülkeler }\end{array}$ \\
\hline Dokümanlar & $\begin{array}{l}\text { En Çok Küresel Atıf Alan } \\
\text { En Çok Küresel Atıf Alan Referanslar } \\
\text { Referans Spektroskopisi } \\
\text { En Sık Kullanılan Kelimeler } \\
\text { Kelime Bulutu } \\
\text { Ağaç Haritası } \\
\text { Kelime Dinamikleri } \\
\text { Trend Konular }\end{array}$ \\
\hline Kavramsal Yapı & $\begin{array}{l}\text { Tematik Harita } \\
\text { Tematik Evrim } \\
\text { Faktöriyel Analiz }\end{array}$ \\
\hline Sosyal Yapı & $\begin{array}{l}\text { Dünya İşbirliği Haritası } \\
\text { İşbirliği A } \mathrm{g} 1\end{array}$ \\
\hline
\end{tabular}

\section{Araştırma Sonuçları ve Tartışma}

\subsection{Araştırma Sonuçları}

Çalışmada analiz edilen 503 adet makale 2001-2019 yılllarını kapsamaktadır. Makalelere ait temel bilgiler Tablo 2'de gösterilmiştir. Tablo 2 incelendiğinde söz konusu makalelerin yayınlandığı 195 adet kaynak (dergi, kitap vs.) bulunmaktadır. Makale başına düşen atıf oranı 22,66'dır. Tek yazarlı makale sayısı 20'dir ve tek yazarlı makalelerin tüm makalelere oranı 0,039'dır. Yazarların iş birliği indeksi 3,83 olmakla beraber bu oran oldukça yüksektir. İş birliği indeksi alanın farklı yazarların birlikte çalışmasına uygun bir alan olduğunu göstermektedir. 
Tablo 2. Veri Seti Hakkında Temel Bilgiler.

\begin{tabular}{|c|c|}
\hline \multirow{2}{*}{\multicolumn{2}{|c|}{$\begin{array}{c}\text { Tanım } \\
\text { VERİ SETI HAKKINDA TFMEI }\end{array}$}} \\
\hline & \\
\hline Zaman Aralığı & 2001:2019 \\
\hline Kaynaklar (Dergiler, Kitaplar, vs.) & 195 \\
\hline Dokümanlar & 503 \\
\hline Yayından İtibaren Ortalama Y1l & 2,35 \\
\hline Doküman Başına Ortalama Alıntı & 22,66 \\
\hline Doküman Başına Yıllık Ortalama Alıntı & 6,361 \\
\hline DOKÜMAN TİPLERİ & \\
\hline Makale & 441 \\
\hline Makale; Kitap Bölümü & 1 \\
\hline Makale; Konge Bildiri (proceedings paper) & 5 \\
\hline Derleme Makalesi & 56 \\
\hline DOKÜMAN İÇERIĞİ & \\
\hline Ek anahtar Kelimeler (Keywords Plus (ID)) & 860 \\
\hline Yazarların Kelime Sayısı & 1649 \\
\hline YAZARLAR & \\
\hline Yazar Sayısı & 1868 \\
\hline Tek Yazarlı Dokümanların Yazar Sayısı & 18 \\
\hline Çok Yazarlı Dokümanların Yazar Sayısı & 1850 \\
\hline YAZARLARIN İȘBİRLIĞ́̇ & \\
\hline Tek Yazarlı Dokümanlar & 20 \\
\hline Yazar Başına Doküman Sayısı & 0,269 \\
\hline Doküman Başına Yazar Sayısı & 3,71 \\
\hline Doküman Başına Ortak Yazar Sayısı & 4,44 \\
\hline İşbirliği Endeksi & 3,83 \\
\hline
\end{tabular}

Şekil 2 incelendiğinde 2001 ve 2014 yılları arasında makale sayılarında düzenli bir artış görülmemekte, 2015 yılı itibari ile ciddi yükselişler gerçekleşmeye başlamaktadır. 2015 yılında 19 olan makale sayısı 2019 yılında 208'e ulaşmıştır. 4 yıl içerisinde yayınlanan makale sayısı 10,94 katına çıkmıştır. 2014 yılına gelindiğinde en yüksek atıf sayısına ulaşıldığı görülmektedir. Fakat 2014 yılından itibaren yıllık ortalama atıf sayılarında sürekli bir düşüş söz konusu olmaya başlamıştır. Ayrıca alanın yıllık büyüme oranı \%56,02 olarak bulunmuştur. Yıllar içerisinde makale sayısındaki ciddi artışlar ve yıllık büyüme oranı alana büyük bir ilginin söz konusu olduğunu, çalışmaların devam ettiğini ve günümüzde güncel bir çalışma alanı olduğunu göstermektedir. Şekilde yer alan doğru ile gelecek yıllarda da alanla alakalı çalışmaların doğrusal bir biçimde artış göstereceği sonucuna ulaşılabilmektedir. Bu doğrultuda makale sayısına ait basit doğrusal regresyon denklemi $\mathrm{y}=6,747368421 \mathrm{x}-$ 13535,73684 şeklinde hesaplanmıştır. Bu denklemde bulunan y değişkeni makale sayısını, $\mathrm{x}$ değişkeni ise yılı temsil etmektedir.

Şekil 2. Makale Sayısının Yıllara Göre Değişimi.

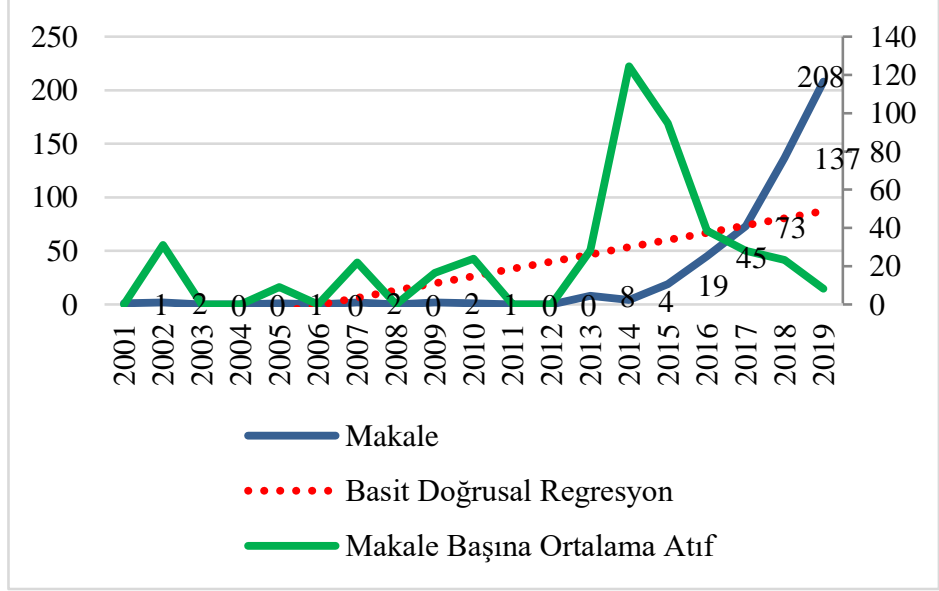

Konu ile alakalı en çok makale yayınlayan dergi ise IEEE Access Dergisi'dir ve dergide konu ile ilgili 59 makale yayınlanmıştır. En alakalı ilk 10 kaynak Şekil 3 (a)'da gösterildiği gibidir. Söz konusu dergide yayınlanan makaleler ilk 20 dergide yayınlanan makalelerin \%21'ini oluşturmaktadır. Dergiye ait websitesi incelendiğinde açık erişimli, multidisipliner ve hakemli bir dergi olduğu anlaşılmaktadır. Düzenli aralıklarla yayın yapan derginin etki faktörü 3,745 olarak belirtilmiştir (IEEE Access, 2020). IEEE Access Dergisi'nden sonra en çok makale yayınlanan dergi Sensors Dergisi'dir ve 35 makale yayınlanmıştır. Sensors Dergisi ise 2001 yılında yayın hayatına başlayan; hakemli, açık erişimli, etki faktörü 3.275 olan bir dergidir (MDPI, 2020). En çok makale yayınlayan diğer dergiler ise 33 makale ile IEEE Internet of Things Journal (IEE IOTJ), 28 makale ile Future Generation Computer Systems-The International Journal of Escience (FGCSTIJOE) ve 19 makale ile Journal of Medical System (JOMS)'dir. En çok makale yayınlayan diğer dergiler ise Applied Scienes-Basel, Journal of Network and Computer Applications (JONACA), Computer Networks, International Journal of Distributed Sensor Networks (IJODSN), Wireless Communication \& Mobile Computing (WCMC) dergileridir. İlk 5 dergide yayınlanan makaleler ilk 20 dergide yayınlanan makalelerin \%63'ünü oluşturmaktadır. Bradford's Yasası'nda bir alandaki çalışmaların genellikle belirli kaynaklarda yayınlandığı ifade edilmektedir. Yayın sayılarına göre kaynaklar azalan bir biçimde sıralandıklarında kaynakların her biri yayınların üçte birini kapsayan üç grupta sınıflandırılabilir. Bu sınıflandırma neticesinde oluşan ilk grup çekirdek kaynakları oluşturmaktadır (Dadkhah, Lagzian, Rahimnia, \& Kimiafar, 2020). Şekil 3(b)'da yer alan dergilerin en ilgili kaynaklarda yer alan ilk 5 dergi ile aynı olduğu göze çarpmaktadır. Bradford Yasası'ndan görüleceği üzere IEEE Access Dergisi'nin temel kaynaklar içerisinde kapladığı alan diğer dergilere oranla daha fazladır. 202 olan toplam dergi sayısının \%2,47'sini çekirdek kaynakların oluşturduğu görülmektedir. Bununla birlikte 5 çekirdek dergide yayınlanan makaleler analizde yer alan tüm makalelerin \%33,52'sini oluşturmaktadır.

Şekil 3. (a) En İlgili Dergiler, (b) Bradford Yasası.

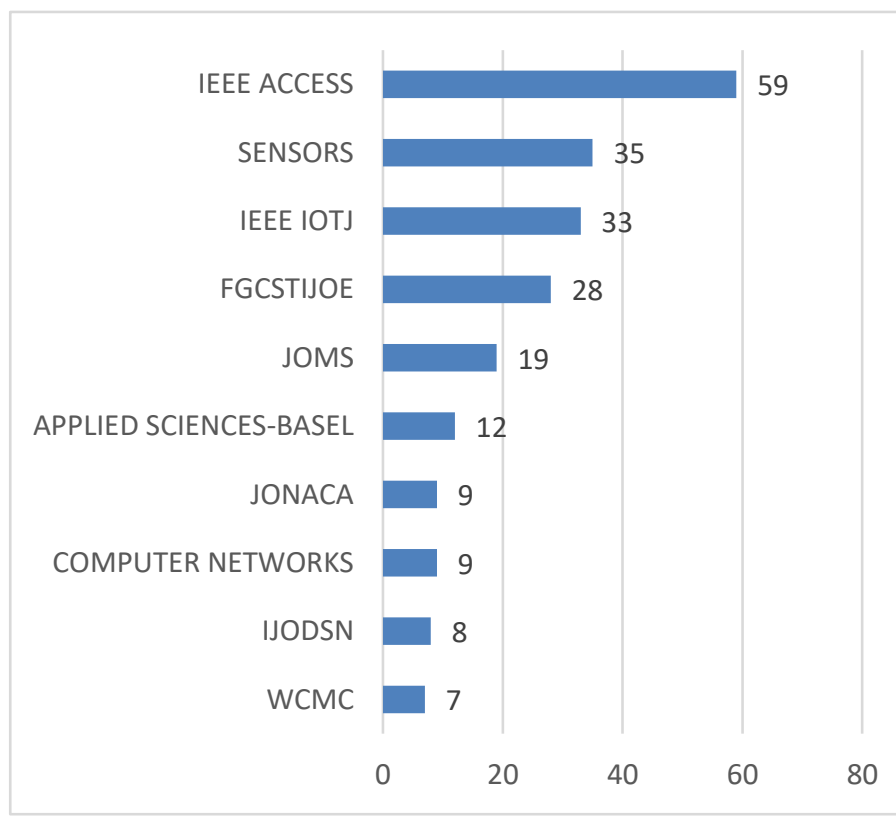

(a) 


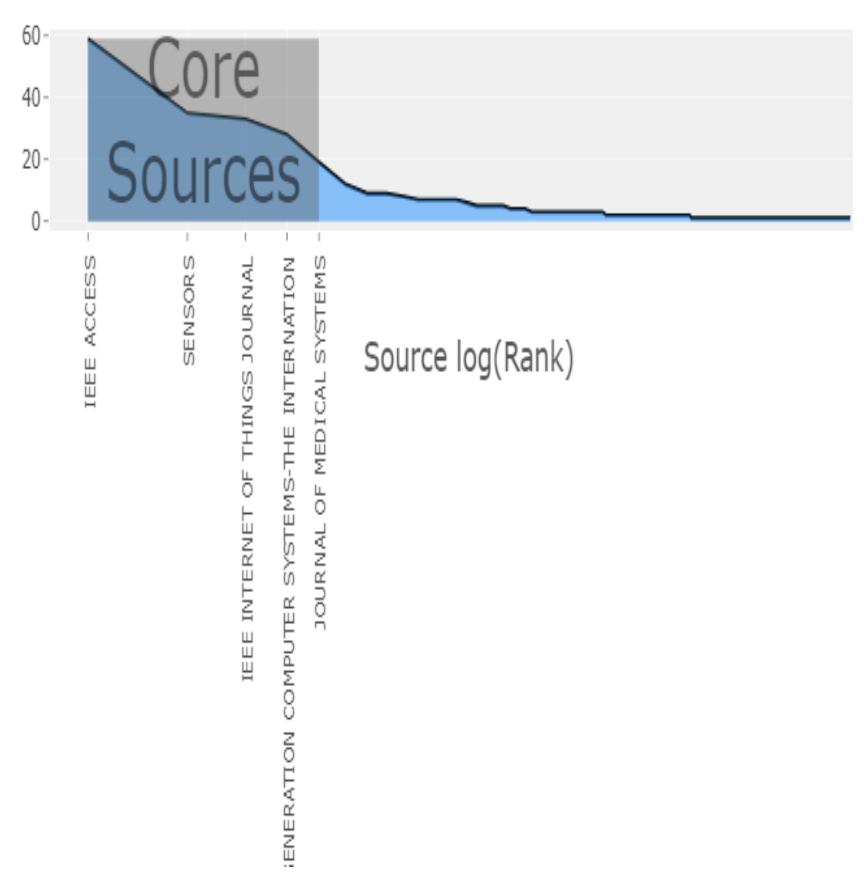

(b)

Kaynaklara ait h, g ve $\mathrm{m}$ indeks değerleri ile toplam atıf sayılarına ilişkin sayısal veriler Tablo 3 'te gösterildiği gibidir. Hirsch h indeksinin alıntı sayısı, makale sayısı ve makale başına ortalama alıntı gibi göstergelere kıyasla gelecekteki başarıyı daha iyi tahmin ettiğini ifade etmiştir (Hirsch, 2007). Tablo 3 incelendiğinde $\mathrm{h}$ indeksi en yüksek kaynağın 19 değeri ile IEEE Access olduğu görülmektedir. Bu indeks dergide yayınlanan 19 makalenin 19'dan fazla atıf aldığını göstermektedir. Aynı zamanda en yüksek $g$ indeksine ve toplam atıf sayısına sahip olma özelliğini de taşımaktadır. Fakat $\mathrm{h}$ indeksi her alanın kendine özgü atıf yöntemi göz önünde bulundurularak hesaplandığ 1 için bizim çalışmamız gibi disiplinlerarası bir çalışmada $\mathrm{h}$ indeksini yorumlamak pek doğru olmayacaktır (Bornmann \& Daniel, 2007). $G$ indeksi ise $h$ indeksinin iyileştirilmiş bir biçimi olarak sunulmuş ve $\mathrm{h}$ indeksi hesaplamalarında farklı sayıda atıf alan makalelerin indekse olan etkisi aynı iken $g$ indeksinde atıf performansı ölçülürken en çok okunan makaleler hesaplamalarda daha çok önemsenmiştir (Egghe, 2006). En yüksek g indeksine sahip kaynak IEEE Access kaynağıdır ve 43 değerine sahiptir. M indeksi Hirsch tarafından tanımlanmıştır ve $\mathrm{H}$ indeksinin akademinin aktif olduğu yıl sayısına bölünmesi ile elde edilmektedir (Harzing, 2012). En yüksek m indeksine sahip kaynak ise Future Generation Computer Systems-The International Journal of Escience kaynağıdır ve 3,4 değerine sahiptir. Toplam atıf sayısı bazında kaynaklar incelendiğinde ise en yüksek atıf sayısına sahip olan kaynağın IEEE Access olduğu ifade edilebilir. IEEE kaynağının en yüksek h ve $g$ indeksleri ile toplam atıf sayısına sahip olmasına rağmen yalnızca m indeksinin Future Generation Computer Systems-The International Journal of Escience kaynağından düşük olması dikkat çekmektedir. İndeksler incelendiğinde en etkin derginin IEEE Access olduğu, güçlü çalışmaların bu dergide yayınlandığı söylenebilir. Alan ile alakalı yapılacak çalışmalarda, alınacak karar ve uygulanacak politikalarda derginin göz önünde bulundurulması önem taşımaktadır.
Tablo 3. Dergilere Ait $h, g, m$ Indeksleri.

\begin{tabular}{|c|c|c|c|c|c|c|}
\hline Dergiler & 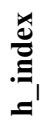 & 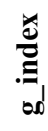 & $\begin{array}{l}\stackrel{0}{\stackrel{0}{0}} \\
\stackrel{\Xi}{\Xi} \\
\mathbf{\Xi}\end{array}$ & U & $\hat{\mathbf{z}}$ & 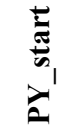 \\
\hline IEEE Access & 19 & 43 & 3,166 & 1925 & 59 & 2015 \\
\hline Future Generation Computer & & & & & & \\
\hline $\begin{array}{l}\text { Systems-The International } \\
\text { Journal of Escience }\end{array}$ & 17 & 28 & 3,4 & 1214 & 28 & 2016 \\
\hline $\begin{array}{l}\text { IEEE Internet of Things } \\
\text { Journal }\end{array}$ & 15 & 33 & 2,142 & 1345 & 33 & 2014 \\
\hline Journal of Medical Systems & 12 & 19 & 2 & 479 & 19 & 2015 \\
\hline Sensors & 11 & 23 & 2,2 & 550 & 35 & 2016 \\
\hline $\begin{array}{l}\text { Journal Of Network And } \\
\text { Computer Applications }\end{array}$ & 7 & 9 & 1,4 & 193 & 9 & 2016 \\
\hline Applied Sciences-Basel & 6 & 11 & 1,2 & 125 & 12 & 2016 \\
\hline Computer Networks & 6 & 9 & 1,2 & 326 & 9 & 2016 \\
\hline $\begin{array}{l}\text { IEEE Communications } \\
\text { Magazine }\end{array}$ & 6 & 7 & 1,5 & 306 & 7 & 2017 \\
\hline $\begin{array}{l}\text { IEEE Transactions On } \\
\text { Industrial Informatics }\end{array}$ & 6 & 6 & 0,857 & 422 & 6 & 2014 \\
\hline
\end{tabular}

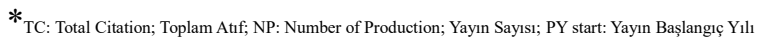

Makale sayısından yıllık büyüme oranı 2014-2019 dönemine özgüdür. Bunun sebebi söz konusu dergilerde alana ait ilk yayının 2014 yılında gerçekleşmiş olmasıdır. 2014 yılından öncesine ait bir çalışma bulunmamaktadır. 2014 yılında yayınlanan ilk makale (Amendola, Lodato, Manzari, Occhiuzzi, \& Marrocco, 2014) makalesidir ve IEEE Iternet of Things Journal Dergisi'nde yayınlanmıştır. Makalede geleneksel tıbbi modelden katılımcı modele geçişte kişisel sağlık bakımının IoT perspektifinden değerlendirilmesi yapılmıştır. Kişilerin günlük hayatlarındaki davranışlar evlerinin içine konan sensörler aracıllğı ile izlenmiştir. Anormal durumlara sebebiyet veren davranışların öncülleri IoT aracıllı̆ı ile incelenmiş ve bu durumlarda hastanın ihtiyaç duyduğu yardımın uzaktan sağlanması için prosedür oluşturulmaya çalışılmıştır (Amendola vd., 2014). Şekil 4 incelendiğinde kaynakların büyüme oranlarında dalgalanmaların olduğu görülmektedir. Kaynaklardan yalnızca IEEE Access yıllar içerisinde doğrusal bir şekilde büyüme göstermiştir. Özellikle Future Generation Computer Systems-The International Journal of Escence ve Journal of Medical System dergilerindeki dalgalanmalar dikkat çekmektedir.

\section{Şekil 4. Kaynaklara Ait Yıllık Büyüme.}

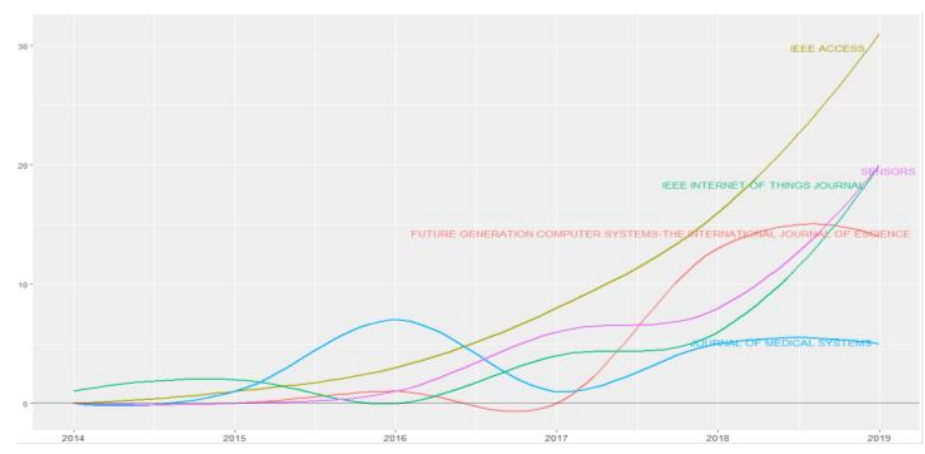

Şekil 5 'te kaynaklarda yıl bazında yayınlanan makale sayıları gösterilmektedir. Görüldüğü üzere IEEE Access Dergisi'nde makale sayısı her yıl artmakta, IEEE Internet of Things Journal 
Dergisi'nde 2016 yılında bir düşüş yaşanmakta fakat diğer yıllarda bir önceki yıla göre yine artmaktadır. Future Generation Computer Systems-The International Journal of Escience Dergisi'nde ilk makale 2016 yılında yayınlanmakta 2017 yılında hiç makale yayınlanmamakta ve 2018 ile 2019 yıllarında makale sayısı artmaktadır. Sensors Dergisi'nde 2016 yılı itibari ile yayın sayısı artmaktadır, Journal of Medical Systems Dergisi'nde ise yayın sayısında dalgalanmalar mevcuttur.

\section{Şekil 5. Yıllara Göre Kaynaklarda Yayınlanan Makale Sayısı.}

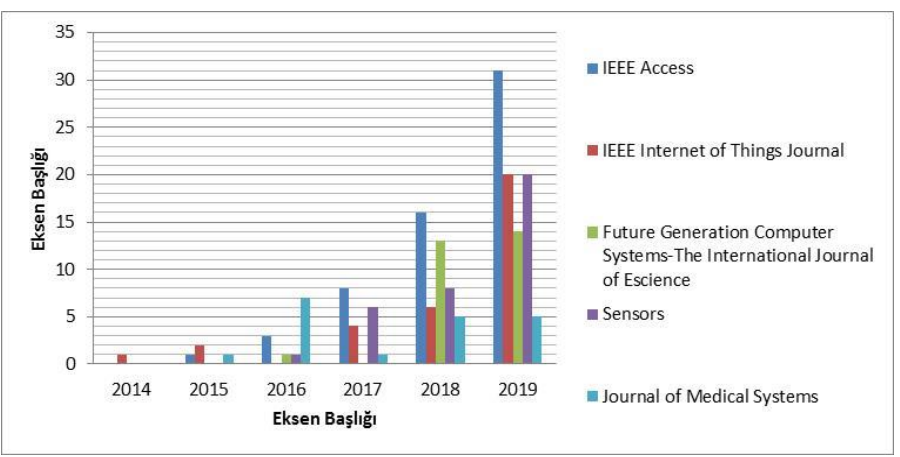

\section{Şekil 6. (a) En Alakalı Yazarlar, (b) Yazarların Zaman Içerisindeki Üretkenliği.}

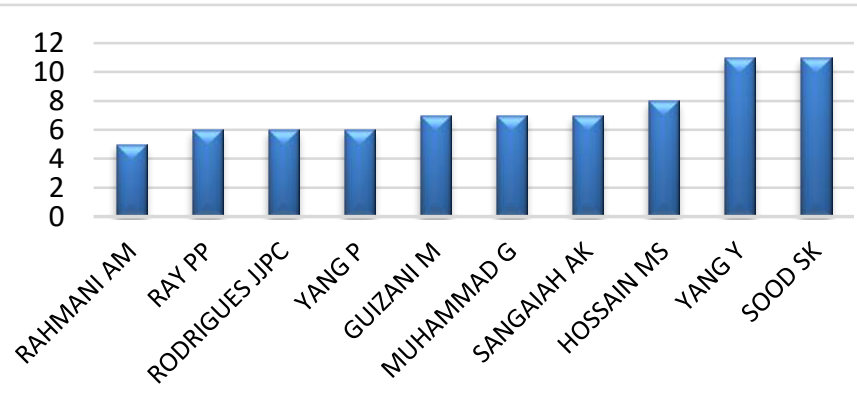

(a)

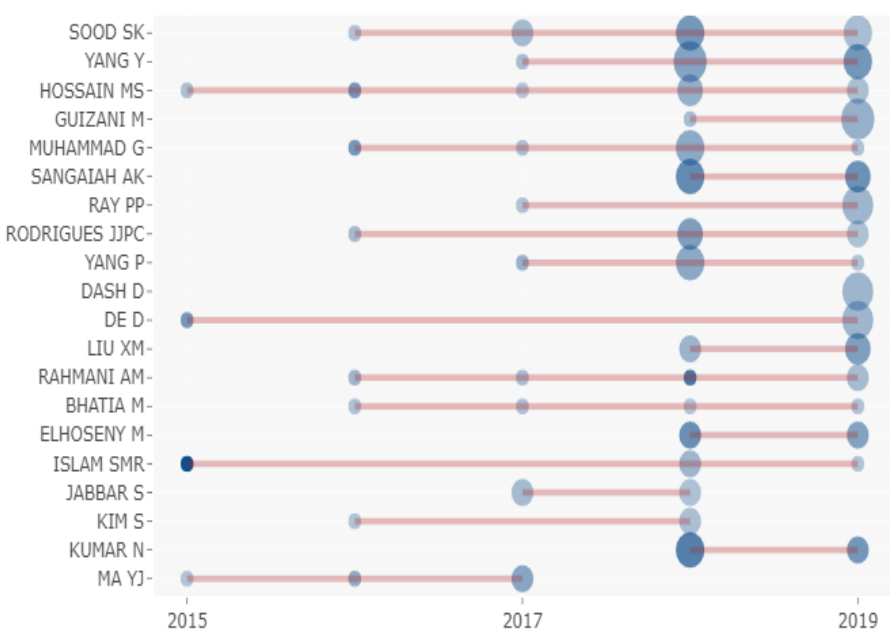

(b)

Kaynaklardan sonra konu ile en alakalı yazarlar da incelenmiştir. En alakalı ilk 10 yazar Şekil 6 (a)'da gösterildiği gibidir. Şekil incelendiğinde en alakalı yazarın Sood SK olduğu görülmektedir ve yazarın alana katkı sağlayan 11 adet makalesi bulunmaktadır. Bir sonraki yazar ise Yang Y'dir ve alana katk1 sağlayan 11 adet makalesi vardır. Fakat bu sonucun elde edilmesinin sebebi programın Yuan Yang, Yutau Yang, Yang Yang ve Yun Yang yazarlarını Yang, Y şeklinde kodlayarak tek bir yazarmış gibi analiz yapmasıdır. Dört yazara ait 11 adet makale, program tarafindan tek yazara ait 11 adet çalışma olarak kabul edilmiş bu sebeple Yang, Y yazarı en alakalı ikinci yazar olarak belirtilmiştir. Yazarların çalışmaları incelendiğinde Yuan Yang ve Yutau Yang'a ait 1, Yang Yang'a ait 4, Yun Yang'a ait 5 adet çalışma olduğu görülmüştür. İnceleme neticesinde kullanılan programın aynı soyisime ve yakın isimlere sahip yazarları kodlamada duyarlı olmadığı görülmüştür. Programın kodlama sorununun çözülmesi analizlerin doğruluk ve güvenilirliğinin arttırılmasını sağlayacaktır. Şekil 6 (b)'de ise en alakalı yazarların üretkenliği incelenerek en üretken ilk 20 yazar gösterilmiştir. Şekilde yer alan yıllar ekseninde yazarların ilk yayını ile son yayını arasında geçen zaman gösterilmektedir. Mavi dairelerin büyüklüğü yayın sayısı ile ilişkilendirilirken; koyuluğu ise yazarların atıf sayıları ile ilişkilidir. Yazarların yayın sayıları arttıkça daire büyümekte, atıf sayıları arttıkça dairelerin rengi koyulaşmaktadır. Şekil incelendiğinde Hossain MS, DE D, Islam SMR ve MA YJ yazarlarının konu hakkında makale yayınlamaya 2015 yılında başladıkları görülmektedir. 2015 yılında en çok atıfı Islam SMR aldığı için 2015 yılını gösteren baloncuğu koyu mavi renklidir. Yazar bir çalışma yayınlamış ve çalışması 757 atıf alarak 2015 yılında en üretken yazar olmasını sağlamıştır. Çalışmada IoT tabanlı sağlık teknolojileri, bu teknolojilerin ağ mimarileri ve endüstriyel eğilimleri incelenerek sağlık hizmetlerinde büyük veri, giyilebilir teknoloji gibi yenilikçi uygulamalardan nasıl yararlanılması gerektiği anlatılmıştır. Uygulamaların güvenlik ve gizlilik özelliklerinden bahsedilmiş ve güvenlik riskini önlemek amacı ile bir model önerilmiştir. Bununla birlikte bazı tanınmış teknoloji firmalarının IoT sağlık hizmeti vizyonları sunulmuştur. Sağlık politikaları sorunlarının ve mevcut durumların ortaya konması amacı ile IoT ve e-sağlık konusunda çalışan ülke ve kuruluşların stratejileri incelenmiştir. Hindistan, Avustralya, Japonya, Çin, Kore, Birleşik Devletler gibi ülkelerin yanısıra Avrupa Birliği ve Dünya Sağlık Örgütü'nün e-sağlık politikaları incelenmiştir (Islam, Kwak, Kabir, Hossain, \& Kwak, 2015).

Islam SMR'den sonra en üretken yazar 2015 yılında yayınladığı bir makale ile 303 atıf alan DE D'dir. Yazar çalışmasında hastanelerdeki ve hemşirelik enstitülerindeki hastaların, personelin ve biyomedikal cihazların otomatik olarak takip edilebilmesi için IoT'ye duyarlı RFID, WSN ve mobil teknolojilerin ortak kullanımını temel alan bir akıllı hastane sistemi önermektedir. Hastanın fizyolojik verileri hastaneye dağılan RFID okuyucular tarafından gerçek zamanlı toplanarak özelleştirilmiş bir web hizmeti aracılığıyla hem yerel hem de uzak kullanıcılar tarafından kolayca erişilebilir hale getirilerek bir kontrol merkezine gönderilir. Önerilen mimariyi doğrulamak için iki farklı kullanım durumu uygulanmıştır. İlki, hastaların izlenmesiyle, ikincisi ise 3 eksenli hılanma ölçümleriyle tespit edilen hasta düşmelerinin neden olduğu acil bir durumun yönetimiyle ilgilidir. Elde edilen sonuçlar, önerilen sistemin sadece hastaneler ve hemşirelik enstitülerindeki hastaların, hemşirelerin ve biyomedikal cihazların takibini gerçekleştirmek için değil uzaktan hasta izleme ve acil durumların ele alınmasını sağlamak için de uygun olduğunu göstermektedir (Catarinucci vd., 2015).

2016 y1lındaki en üretken yazarlar ise Hossain MS ve Muhammad G'dir. Yazarların ortak çalışması olan makale 245 atıf almıştır. Çalışmada sağlık verilerinin mobil cihazlar ve sensörler tarafindan toplandığı ve sağlık uzmanları tarafından sorunsuz erişim için buluta güvenli bir şekilde gönderildiği mimari 
sunulmuştur. Önerilen sistemde kimlik hırsızlığını veya klinik hatayı önlemek için sinyal geliştirme, filigranlama gibi analizlerin kullanılması önerilmiştir. Sağlık hizmeti verilerinin güvenli ve yüksek kaliteli izlenmesi için buluta gönderilmeden önce filigran haline getirildiği buluta entegre bir çerçeve açıklanmıştır. Gelecekteki çalışmalarının gerçek dünyadaki hastalar ve sağlık uzmanlarıyla bir test denemesinin uygulamasını içereceğini belirtmişlerdir (Hossain \& Muhammad, 2016).

2017 yılındaki en üretken yazar ise MA YJ'dir yazarın 2017 yılında yayınladığı iki adet çalışması vardır. 110 atıf alan çalışmasında mevcut sağlık hizmetinin dezavantajları incelenmiş yeni nesil sağlık bakım sistemlerinin deneyim ve hizmet kalitesini iyileştirmek için Giyilebilir 2.0 sağlık sistemi önerilmiştir. Önerilen sistemde, sensörler ve elektrotlardan oluşan yıkanabilir akıllı giysiler, kullanıcıların bulut tabanlı makine zekası tarafindan sağlanan fizyolojik verilerini toplayarak sağlık ve duygusal durumlarını analiz etmek için kritik bir bileşendir (Chen vd., 2017). Web of Science veri tabanında yayınlanan diğer çalışması ise 24 atıf almıştır çalışmada nesne tabanlı sağlık sistemine ve büyük veriye dayalı uygulama açıklanmışır. Sistemin mimarisi, anahtar teknolojileri ve tipik uygulamaları tanıtılmış ve zorlukları ortaya konmuştur (MA, Wang, Yang, Miao, \& Li, 2016).

2018 yılındaki en üretken yazar ise Rahmani AM'dir yazarın 2018 yılında yayınladığı çalışması 251 atıf almıştır. Yazar çalışmasında yerel depolama, gerçek zamanlı yerel veri işleme, gömülü veri madenciliği gibi üst düzey hizmetler sunmak için bir Akıllı e-Sağlık Geçidi sunmaktadır. Sensör düğümleri ve bulut arasında Geo-dağıtılmış bir ara zeka katmanı oluşturarak sağlık hizmeti IoT sistemlerinde Sis Bilişim konseptinden yararlanmayı önermiştir. Önerilen mimarinin sensör ağının ve uzaktaki bir sağlık bakım merkezinin bazı yüklerinin üstesinden gelme sorumluluğunu alarak, mobilite, enerji verimliliği, ölçeklenebilirlik ve güvenilirlik sorunları gibi sağlık hizmetleri sistemlerindeki zorluklarla başa çıkabileceğini ifade etmişlerdir. Ayrıca, tartışılan bazı üst düzey özelliklerin uygulandığı UTGATE adlı bir Akıllı e-Sağlık A ̆g Geçidi prototipi sunulmuş ve sistemin vaka çalışmasını ele almadaki etkinliğini pratikte göstermek için IoT tabanlı bir erken uyarı puanı uygulanmıştır (Rahmani vd., 2018).

2019 yılının en üretken yazarı ise Sangaiah AK'dir. Yazarın 2019 yılında 3 çalışması vardır ve çalışmaları 112 atıf almıştır. 71 atıf alan çalışmasında sağlık hizmeti uygulamalarındaki çeşitli sorunları çözmek için bulut bilişim ve IoT uygulamalarının literatürü kapsamlı bir şekilde incelenmiş ve sağlık uygulamaları için bulut bilişsim ile IoT'nin entegrasyonu önerilmiştir. Sağlık sistemleri için bulut bilişim ve IoT entegrasyonu araştırmaları incelenmiş, zorluklar ve gelecekteki araştırma eğilimleri belirlenerek CloudIoT-Health teknolojisi analiz edilmiştir. (Darwish, Hassanien, Elhoseny, Sangaiah, \& Muhammmad, 2019).

Yazarlara ait h, g ve m indeks değerleri ile toplam atıf sayısı Tablo 4'te incelenmiştir. En yüksek h indeksine sahip yazarın 8 değeri ile Yang Y olduğu görülmektedir. En yüksek g indeksine sahip yazarın 11 değeri ile Sood SK, en yüksek m indeksine sahip yazarın ise 2,333 değeri ile Sangaiah AK olduğu sonucuna varılmıştır. En alakalı yazarların incelendiği analiz ile karşılaştırıldığında sonuçların anlamlı olduğu görülmektedir.
Tablo 4. Yazarlara Ait h, g, m Indeksleri ile Toplam Atıf Sayılart.

\begin{tabular}{|c|c|c|c|c|c|c|}
\hline Yazar & 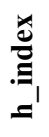 & 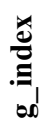 & 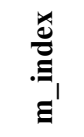 & $\bigcup^{*}$ & 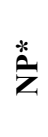 & 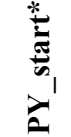 \\
\hline YANG Y & 8 & 10 & 2 & 249 & 10 & 2017 \\
\hline SOOD SK & 7 & 11 & 1,4 & 235 & 11 & 2016 \\
\hline MUHAMMAD G & 7 & 7 & 1,4 & 370 & 7 & 2016 \\
\hline SANGAIAH AK & 7 & 7 & 2,333 & 299 & 7 & 2018 \\
\hline HOSSAIN MS & 6 & 8 & 1 & 378 & 8 & 2015 \\
\hline GUIZANI M & 6 & 7 & 2 & 73 & 7 & 2018 \\
\hline YANG P & 6 & 6 & 1,5 & 193 & 6 & 2017 \\
\hline RODRIGUES JJPC & 5 & 6 & 1 & 194 & 6 & 2016 \\
\hline RAHMANI AM & 5 & 5 & 1 & 392 & 5 & 2016 \\
\hline RAY PP & 4 & 6 & 1 & 48 & 6 & 2017 \\
\hline
\end{tabular}

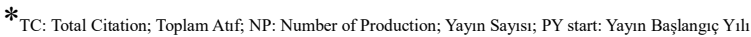

Lotka Kanunu'na göre ise bir alana $\mathrm{x}$ kadar katkıda bulunan yazar sayısı alana katkıda bulunanların tamamının 1/x2 kadarıdır. Lotka Yasası ile yazarların çalıştıkları alanlara gelecek dönemlerde sağlayabilecekleri katkı ölçülmeye çalışılmaktadır. Ölçümlerde yazarların yayın yapma sıklığı göz önünde bulundurulmaktadır. Derginin Lotka Yasası'na uygun bir biçimde yayın yapıyor kabul edilebilmesi için yazarların \%60'nın bir makaleyle dergiye katkı sağlaması, \%15'nin iki makaleyle, $\% 7$ 'sinin ise üç makaleyle katkı sağlaması gerekmektedir (Lotka, 1926; Potter, 1988; Rowlands, 2004). Sağlık hizmetlerinde IoT uygulamaları alanına yazarların $\% 88,1$ 'i bir makale ile, $\% 8,1$ 'i iki makale ile ve \%2,4'ü üç makale ile katkıda bulunmuştur. Bu durumda alandaki yazar dağılımının Lotka Yasası'na uymadığı görülmektedir.

\section{Şekil 7. Lotka Kanunu.}

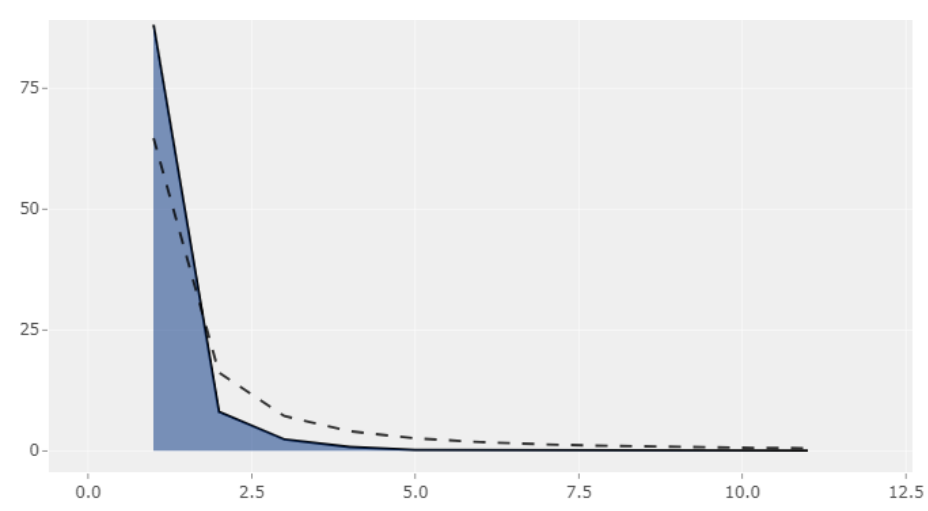

Sekil 8'de yazarların birlikte bulunabilirlikleri (co author analizi) incelendiğinde 22 kümenin oluştuğu görülmektedir. Kümeler yazarların çalışmalarında işledikleri konunun benzerliğine göre oluşmaktadır. Alanın birbirine benzeyen veya aynı konularını çalışan yazarları bir küme oluşturmaktadır. Zaidan AA, Zaidan BB, Albahri AS, Alamoodi AH, Albahri OS, Alsalem MA ve Mohammed KI kümesini oluşturan yazarların birlikte çalıştıkları iki makale olduğu ve makalelerinde sağlık alanında IoT uygulamalarının gerçek zamanlı veri elde etmek amacı ile giyilebilir teknolojiler kısmını inceledikleri görülmektedir (Albahri vd., 2019; Talal vd., 2019). Hossain MS ve Muhammad G'nin oluşturduğu kümede yer alan makaleler incelendiğinde yazarların bir başka yazarlarla beraber yayınlanan 3 adet, yalnızca ikisinin yayınladığı ise 2 adet çalışmaları bulunmaktadır. Çalışmalarında bulut teknolojisini kullanrak IoT tabanlı bir 
bilişsel sağlık hizmeti mimarisi önermişlerdir. Hastalardan gelen EEG sinyallerinin IoT cihazları aracılığıyla buluta iletilip işlenmesine ve bilişsel bir modüle gönderilmesine dayanan bir uygulama gerçekleştirmişlerdir. Önerdikleri mimaride hastalara ait verilerin eş anlı izlenerek hizmet sağlayıcısına iletilmesi sağlanır (Amin, Hossain, Muhammed, Alhussein, \& Rahman, 2019). Söz konusu mimarilerini epileptik nöbetin algılanması amacı ile de geliştirmişler ve \%99,2 oranında doğruluk, \%93,5 oranında bir hassasiyet yakalamışlardır (Alhussein, Muhammad, Hossain, \& Amin, 2018). Güvenlik sorunu da çalışma alanları içerisinde bulunmakta olup tele-sağllk sistemlerinde güvenilir hizmet sunumunun gerçekleştirilmesi için bir yöntem önermişlerdir. Önerdikleri yöntemin IoT ve bulut bilişim üzerinde uygulanan tele-sağlık hizmetlerinin güvenilirliğini arttırdığını ifade etmişlerdir (Rawashdeh vd., 2018). Yazarların ikisinin ortak çalışmalarında ise sağlık hizmeti verilerinin mobil cihazlar ve sensörler tarafından toplanarak hizmet sunucularının erişmesi için buluta güvenli bir şekilde gönderildiği bir çerçeve sunulmuştur. Uygulamada kimlik hırsızlığı ve klinik hata gibi durumları önlemek için çeşitli analizler gerçekleştirilmiştir (Hossain \& Muhammad, 2016). Yine ortak bir diğer çalışmalarında ise duyguya duyarlı bir sağlık sistemi önerilmiş, çalışmalarında hastanın konuşma ve görüntü sinyallerini yakalamak için farklı IoT cihazları kullanılmıştır. Konuşma ve görüntü sinyalleri ayrı ayrı işlenmektedir ve hissedilen duygu kararının verilmesi için birleştirilmektedir. Duygu durumu acı olarak algılanırsa bakıcıların hastayı ziyaret etmesi tasarlanmıştır. Yapılan deneyler neticesinde duygu algilamada \%99,87'ye varan doğruluk elde edilmiştir (Hossain \& Muhammad, 2017). Sangaiah AK, Elhoseny M, Muhammad K, Li X, Kumari S, Sheen J ve Wu F'nin yer aldığı ayrı bir kümenin oluştuğu görülmektedir. Sangaiah AK çalışmasında sağlık hizmetlerinde büyük veriyi verimli bir biçimde yönetmek için model önermektedir. Çeşitli kaynaklardan gelen verilerin insan müdahalesi olmadan işlendiği, analiz edildiği modelde sağlık hizmetleri sistemlerinin performansının iyileştirildiği ifade edilmiştir (Elhoseny vd., 2018). Sistemi iyileştirmek amacı ile yaptığı bir diğer çalışmada ise farklı mesajlardaki farklı imzaları tek bir imzayla eşleştiren bir şema önermiştir (P. Kumar, Kumari, Sangaiah, Wei, \& Li, 2018). Kişilerin kendi sağlık durumları konusunda sorumluluk almalarını ifade eden bilgi merkezli bağlantılı sağlık hizmetleri kavramını öne çıkarmıştır. Acil durumlarda kendi kendine bakımın gerçekleştirilmesini sağlamak üzere verilerin işlenmesi için bir uç öğrenme modeli geliştirmiştir ( $\mathrm{Li}, \mathrm{Xu}$, Sangaiah, Wu, \& Li, 2019). Yazarın verilerimiz arasında yer alan diğer makaleleri incelendiğinde ise bilgi aktarımının verimliliğini arttırmak için tıbbi nesnelerin interneti ile ürün yaşam döngüsü yönetimini entegre edildiği (Sodhro, Pirbhulal, \& Sangaiah, 2018), kişiselleştirilmiş sağlık sistemlerinde kablosuz tıbbi sensör ağlarının güvenliğini sağlamak üzere bir kimlik doğrulama şeması önerildiği (Wu vd., 2018) ayrıca nesnelerin interneti ve bulut bilişiminin sağllk hizmetlerine olan etkilerinin incelenerek konunun firsatlarının ve zorluklarının değerlendirildiği (Darwish vd., 2019) görülmektedir. Yang Y, Yang P, Xu LD ve Liu XM'nin oluşturduğu kümede yer alan yazarların tamamının ortak çalışması bulunmamakla birlikte Yang Y'nin Yang, P ile 3 adet ortak çalışması bulunmaktadır. Fiziksel aktivite tanıma ve izleme çalışmalarını IoT perspektifinden değerlendirerek sistematik bir çalışma yapmışlar araştırma eğilimlerini, zorlukları inceleyerek gelecekteki uygulamaları belirlemeye çalışmışlardır (Qi vd., 2018). Ayrıca Çin'de yaşlılara yönelik olarak mobil sağlık hizmetlerinde kullanıcı profilinin tanımlanması ve oluşturulması amacı ile yeni bir yöntem ile (Xie, Cai, Yang, Jiang, \& Yang,
2018) IoT tabanlı sağlık hizmetlerinde klinik karar vermeyi desteklemek için bir yarı denetimli öğrenme yaklaşımı önermişlerdir (Yun Yang vd., 2019). Rodrigues JJPC, Saleem, K ve De Albuquerque, VHC' nin oluşturduğu küme incelendiğinde Saleem K'nin 5 adet çalışmasının olduğu bu çalışmalardan 3'ünü Rodrigues, JJPC ile birlikte yayınladığı görülmektedir. Ortak çalışmalarında sağlık hizmetlerinde enerjiye duyarlı sis bulutu (Mahmoud, Rodrigues, Saleem, Al Muhtadi, \& Korotaev, 2018), e-sağlık uygulamalarında sis destekli çözümün performans değerlendirmesi (Vilela, Rodrigues, Solic, Saleem, \& Furtado, 2019) ve mobil sağlık uygulamalarında akıllı kişisel asistanlar için IoT tabanlı mobil ağ geçidi (Santos vd., 2016a) konularını ele almışlardır. De Albuquerque, VHC' nin ise 2 adet çalışmasının olduğu ve ikisini de Rodrigues, JJPC ile birlikte yayınladığg görülmektedir. Ortak çalışmalarında akıllı sağlık hizmetlerinde bulut teknolojilerini etkinleştirme (Mahmoud, Rodrigues, Ahmed, vd., 2018) ve kan şekerinin sürekli izlenmesi ve yönetilmesi için elektronik ve mobil sağlık sistemlerine dayalı nesnelerin interneti (Barata, Munoz, De Carvalho Silva, Rodrigues, \& Albuquerque, 2019) konularında çalışmışlardır.

\section{Şekil 8. Yazarların Birlikte Bulunabilirliği.}

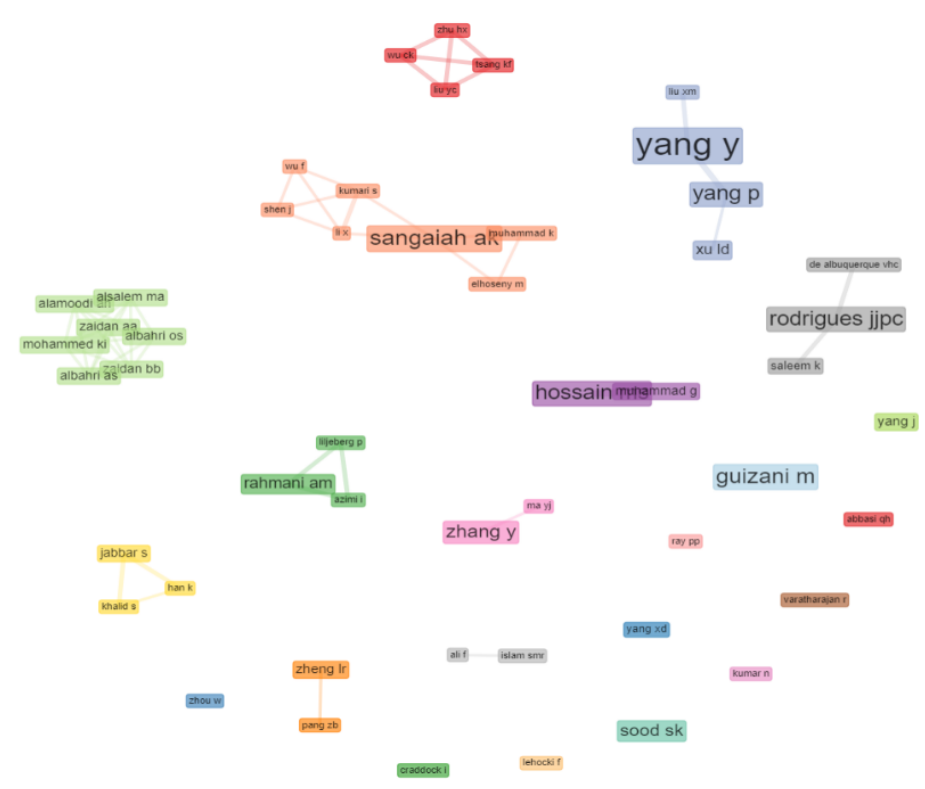

Yazarların bağlı bulunduğu ülkeler incelendiğinde ise en çok makalenin Çin tarafından yayınlandığı görülmektedir. Şekil 9 (a)'da ilgili yazarların ülkeleri gösterilmektedir. Birden fazla ülkeden yazarların iş birliği ile oluşturulan yayınlar MCP (Multiple Country Production; Çok sayıda ülkenin işbirliğine dayalı makale üretimi) oranı ile ifade edilmektedir. SCP (Single Country Production; Sadece bir ülkenin tek başına hiçbir uluslarrası işbrliğine gitmeden gerçekleşitirdiği makale üretim süreci) oranında ise aynı ülkeye ait yazarların yayınları değerlendirilmektedir. Çin'in MCP oranının diğer ülkelere kıyasla daha yüksek olduğu görülmektedir. Bu durumda Çin'in iş birliğine diğer ülkelere kıyasla daha açık olduğu ifade edilebilir. Çinli yazarların diğer ülkedeki meslektaşları ile daha fazla işbirliği yaptıkları görülmektedir. Şekil 9 (b)'de ise en çok alıntı yapılan ülkeler gösterilmektedir. Çin 2306 alıntı ile en çok alıntı yapılan ülkedir. Konu ile alakalı olarak yapılan çalışmalarda veya politika yapıcılar tarafınan alınan kararlarda Çin'in takip edilmesi ilgililere yarar sağlayacaktır. Ülkelerin bilim üretiminin yer aldığ analizde de en büyük payın Çin'e ait olması bulguyu destekler niteliktedir. 
Şekil 9. (a) Sorumlu Yazarın Ülkesi, (b) En Çok Alıntı Yapılan Ülkeler.

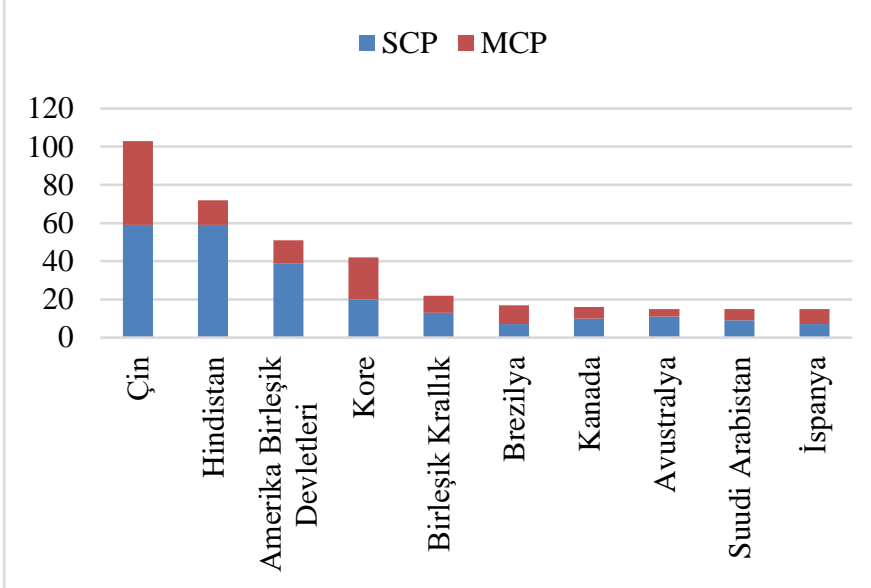

(a)

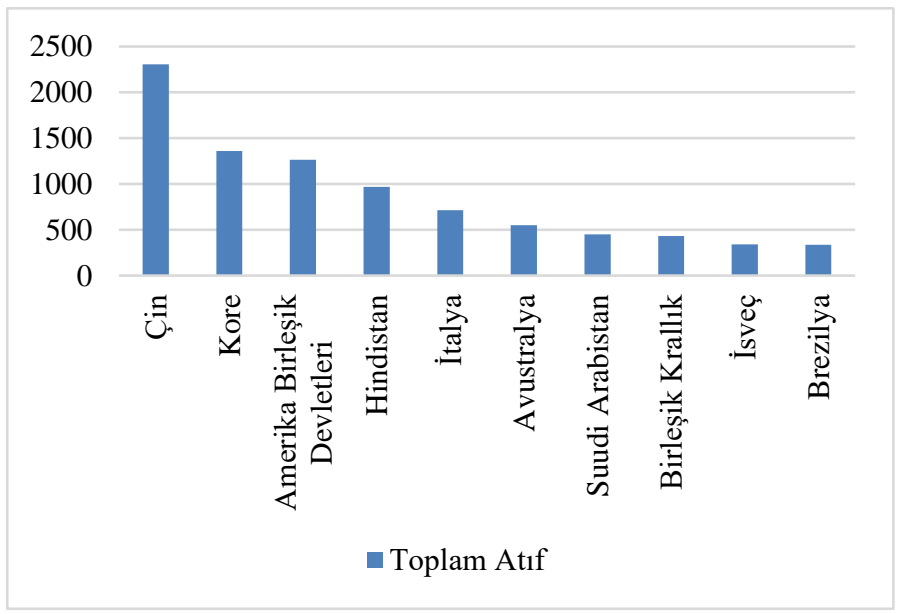

(b)

Konuya en çok katkı yapan, en üretken ülke 302 çalışma ile Çin'dir. Çin'i 182 çalışma ile Amerika Birleşik Devletleri takip etmektedir. Şekil 10 'da en çok makale yayınlayan ilk 10 ülke gösterilmektedir.

Şekil 10. Ülkelerin Bilim Üretimi.

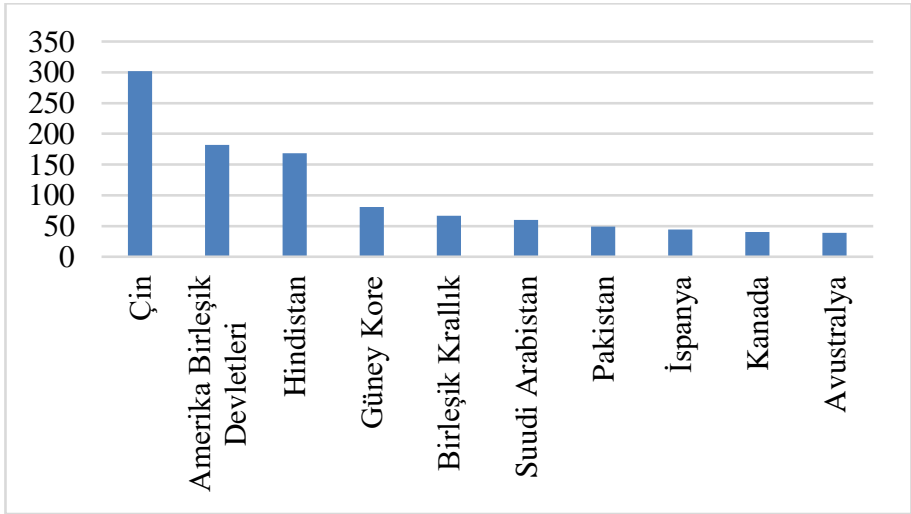

Ülkelerin iş birliği ağı ise Şekil 11'de gösterildiği gibidir. Şekli desteklemesi amacı ile ülkelerin iş birliğine ait sayısal veriler Tablo 5'te sunulmaktadır. Amerika Birleşik Devletleri ile Çin arasındaki iş birliğinin yüksek olduğu görülmektedir.
Şekil 11. Ülkelerin Işs Birliği A $\breve{g}$.

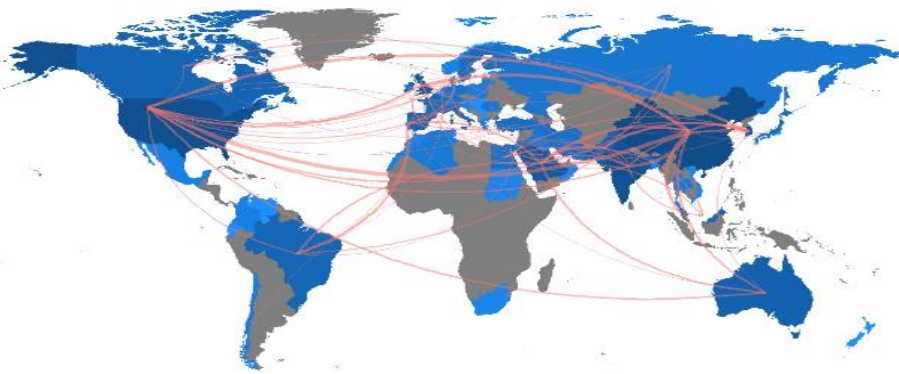

Tablo 5. Ülkelerin Işs Birliğine Ait Saylsal Veriler.

\begin{tabular}{l|l|c}
\hline \multicolumn{1}{c|}{ Ülkeden } & \multicolumn{1}{c|}{ Ülkeye } & Frekans \\
\hline ABD & ÇİN & 18 \\
ÇIN & İNGILTERE & 13 \\
KORE & ABD & 11 \\
HINDİSTAN & ÇİN & 10 \\
PAKİSTAN & SUUDİ ARABİSTAN & 10 \\
ÇIN & SİNGAPUR & 8 \\
BREZILYA & PORTEKİZ & 7 \\
ÇIN & SUUDİ ARABİSTAN & 7 \\
KORE & ÇİN & 7 \\
KORE & PAKİSTAN & 7 \\
ABD & İNGILTERE & 7 \\
KORE & HİNDİSTAN & 6 \\
SUUDİ ARABİSTAN & AUSTRALYA & 6 \\
SUUDİ ARABİSTAN & PORTEKIZ & 6 \\
ABD & SUUDİ ARABİSTAN & 6 \\
\hline
\end{tabular}

Global düzeyde en çok alıntı yapılan dokümanlar Şekil 12'de gösterilmektedir. Şekle göre en çok alıntı yapılan doküman Islam SMR'nin 2015 yılında yazmış olduğu IEEE Access'te yayınlanan çalışmasıdır. Çalışma 757 atıf almıştır ve çalışmanın yıllık atıf sayıs1 126,167'dir. En çok alıntı yapılan 2. doküman ise Catarinucci L'nin 2015 yılında yazmış olduğu IEEE Internet Things'te yayınlanan çalışmadır. Çalı̧̧ma 303 atıf almıştır ve yıllık toplam atıf sayıs $50,5^{\prime}$ tir. En çok alıntı yapılan dokümanların konu ile en alakalı dergilerde yayınlanan çalışmalar oldukları görülmektedir.

Şekil 12. En Çok Global Alıntı Yapılan Dokümanlar.

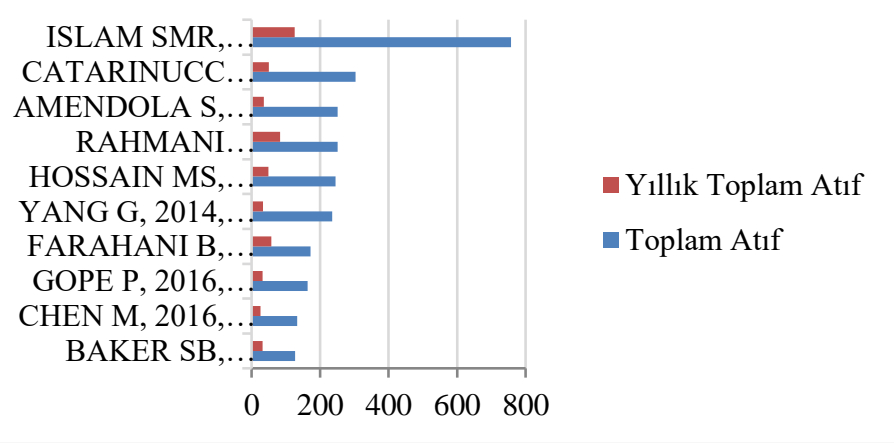

Makalelerde en sık kullanılan kelimeler özet, anahtar kelime, kaynakça ve başlık düzeyinde analiz edilmiştir. Tablo 6 incelendiğinde makalelerin özet kısımlarında data kelimesinin $1167 \mathrm{kez}$, anahtar kelime kısımlarında internet of things kelime grubunun $135 \mathrm{kez}$, kaynakça kısımlarında internet kelimesinin 157 kez ve başlık kısımlarında ise healthcare kelimesinin $236 \mathrm{kez}$ kullanıldığı görülmektedir. En sık kullanılan kelimeler genel bir biçimde incelendiğinde kelimelerin hem sağlık alanına ait 420 
terimler hem de mühendislik alanına ait terimler olduğu sonucuna ulaşılabilmektedir.

Tablo 6. Özet, Anahtar Kelime, Kaynakça ve Başlıklarda En Sık Kullanılan Kelimeler.

\begin{tabular}{|c|c|c|}
\hline & Kavram & Siklık \\
\hline Özet & $\begin{array}{l}\text { data } \\
\text { health } \\
\text { healthcare } \\
\text { iot } \\
\text { system } \\
\text { proposed } \\
\text { internet } \\
\text { things } \\
\text { medical } \\
\text { smart }\end{array}$ & $\begin{array}{l}1167 \\
953 \\
930 \\
698 \\
565 \\
519 \\
517 \\
455 \\
397 \\
397\end{array}$ \\
\hline Anahtar Kelime & $\begin{array}{l}\text { internet of things } \\
\text { healthcare } \\
\text { internet of things (iot) } \\
\text { iot } \\
\text { cloud computing } \\
\text { security } \\
\text { privacy } \\
\text { e-health } \\
\text { big data } \\
\text { sensors }\end{array}$ & $\begin{array}{c}135 \\
77 \\
54 \\
45 \\
37 \\
35 \\
32 \\
25 \\
23 \\
22\end{array}$ \\
\hline Kaynakça & $\begin{array}{l}\text { internet } \\
\text { things } \\
\text { system } \\
\text { care } \\
\text { framework } \\
\text { cloud } \\
\text { iot } \\
\text { big data } \\
\text { challenges } \\
\text { security }\end{array}$ & $\begin{array}{l}157 \\
108 \\
63 \\
45 \\
40 \\
30 \\
29 \\
27 \\
27 \\
26\end{array}$ \\
\hline Başlık & $\begin{array}{l}\text { healthcare } \\
\text { health } \\
\text { internet } \\
\text { system } \\
\text { things } \\
\text { monitoring } \\
\text { smart } \\
\text { iot } \\
\text { data } \\
\text { based }\end{array}$ & $\begin{array}{l}236 \\
206 \\
108 \\
108 \\
106 \\
105 \\
96 \\
90 \\
74 \\
64\end{array}$ \\
\hline
\end{tabular}

Makalelerde en s1k kullanılan kelimeler kelime bulutları grafikleri aracılığı ile Şekil 13'de görselleştirilmiştir. Görsellerde kelimelerin büyük puntolar ile yazılması kullanım sıklığını ifade etmektedir. Bir kelime ne kadar büyük puntolar ile yazılmışsa o kadar sık kullanılmıştır.
Şekil 13. (a) Özetlerin Kelime Analizi, (b) Anahtar Kelimelerin Kelime Analizi, (c) Kaynakçaların Kelime Analizi, (d) Başlıkların Kelime Analizi.

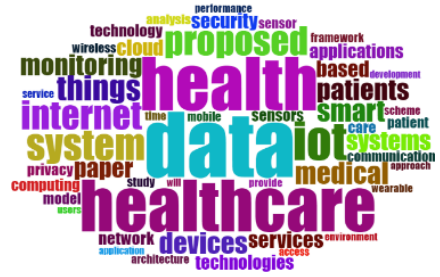

(a)

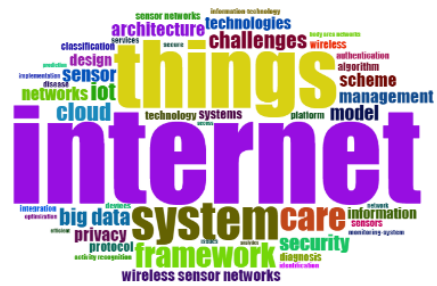

(c)

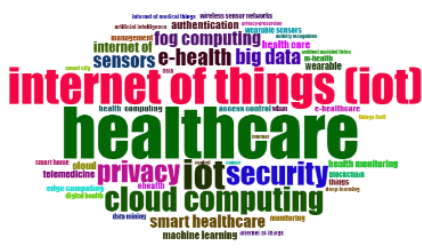

(b)

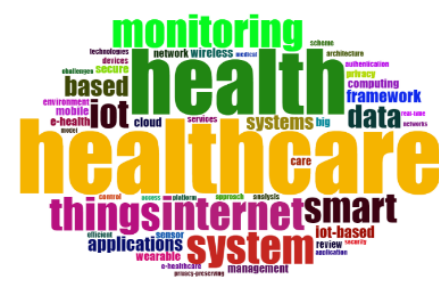

(d)
En çok kullanılan ilk 10 kelimenin yıllara göre kullanım sıklığı incelendiğinde özellikle 2014 yılından sonra kelimelerin kullanımında bir artışın söz konusu olduğu görülmektedir. Şekil 14 (a)'da big data (büyük veri) kelime grubunun anahtar kelimelerde kullanımının, Şekil 14 (c)'de ise cloud (bulut) kelimesinin kaynakçada kullanımının 2019 yılında azaldığı dikkat çekmektedir. Son yıllarda security ve privacy gibi kavramların en sık işlenen kavramlar arasında yer alması araştırmacıların sağlık hizmet kullanımında gizliliğe ve güvenilirliğe önem verdiğini göstermektedir.

Şekil 14. (a) Özetlerin Kelime Dinamikleri, (b) Anahtar

Kelimelerin Kelime Dinamikleri, (c) Kaynakçaların Kelime Dinamikleri, (d) Başlıkların Kelime Dinamikleri.

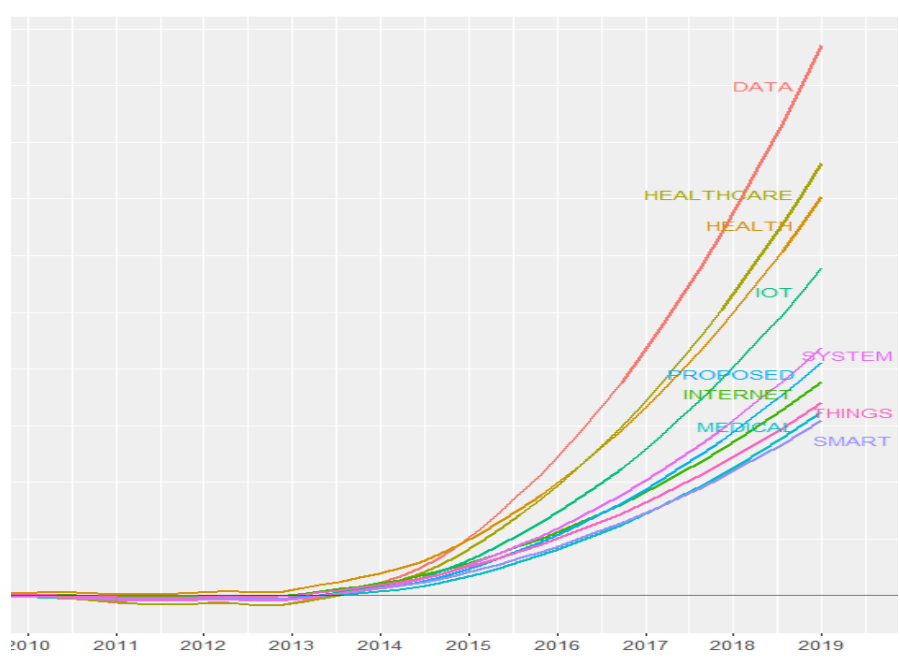

(a) 


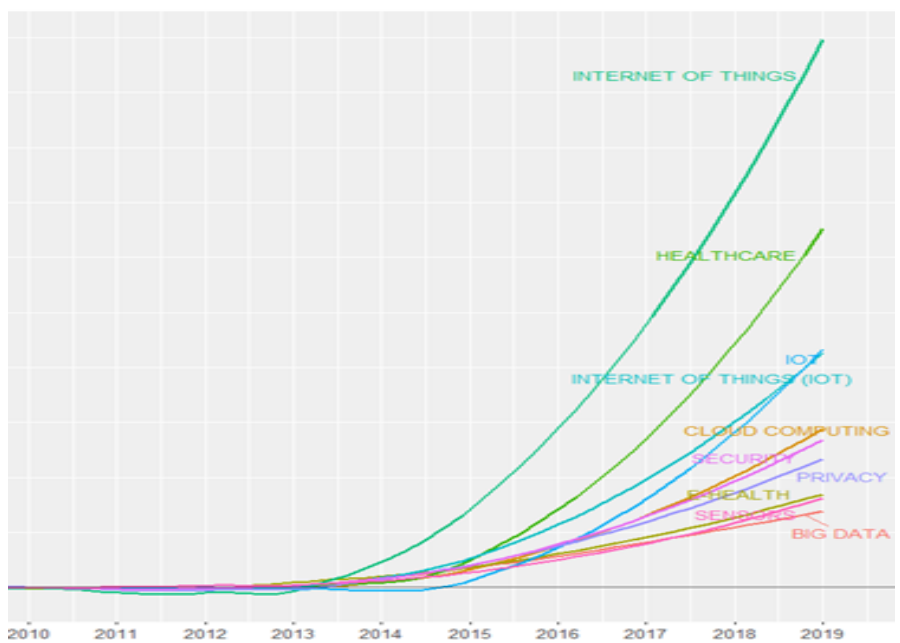

(b)

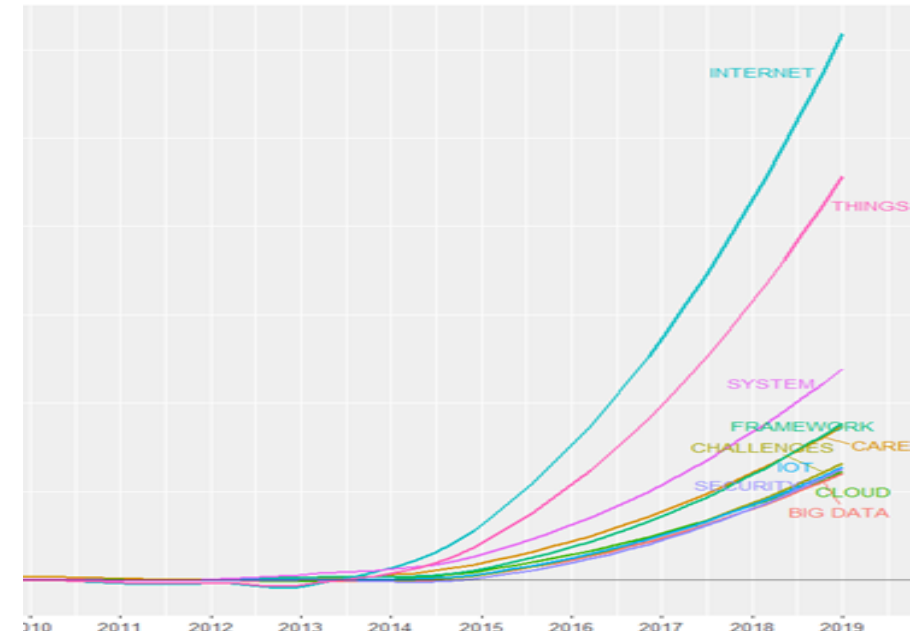

(c)

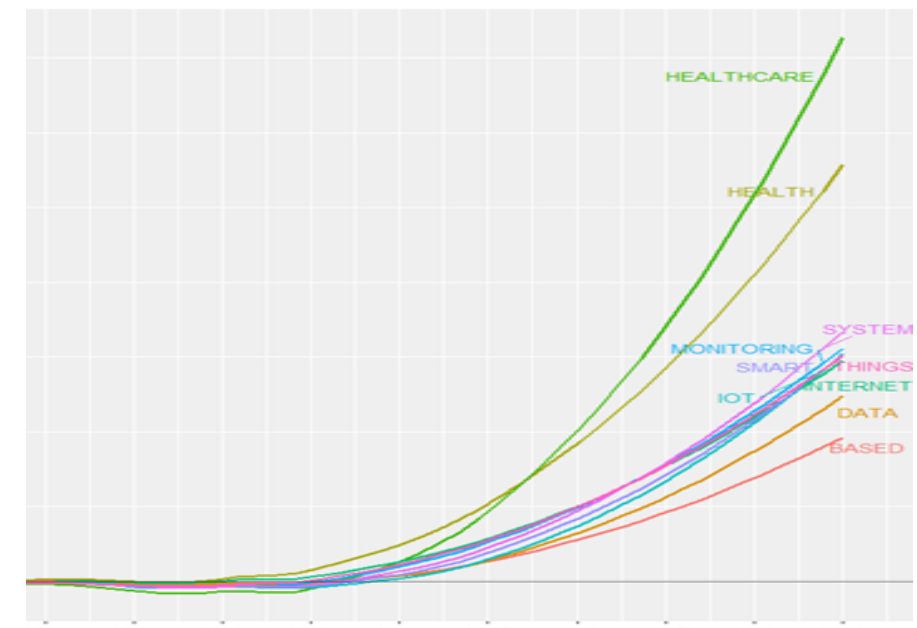

(d)

Tematik değişim kelimelerin nasıl kullanılmaya başlandığını ve zaman içerisindeki değişimlerini ifade etmektedir. Şekil 15 (a)'da özet kısmında yer alan kelimelerin tematik değişimi gösterilmektedir. 2001-2014 yılları arasındaki data, internet, medical ve health kavramlarının güncel olduğu görülmektedir. Data; paper, internet ve based kelimelerini yıllar içerisinde beslemiştir. 2001-2014 yıllarında güncel olan data kavramı 2018-
2020 'de de güncelliğini korumuştur. İnternet ise daha çok kendisini beslemekle beraber paper, based ve healthcare kavramlarını da beslemiştir. 2001-2014 yılları arasında güncel bir kavram olan internet 2018-2020 arasında güncelliğinin yanı sıra oldukça büyüyen, diğer kavramlar tarafından beslenen bir kavrama dönüşmüştür. Medical paper ve healthcare kavramlarını; health ise yalnızca internet kavramını beslemiştir. 2015-2017 yıllarında paper kavramı data, health ve internet kavramlarını; internet kavramı data, health, internet ve monitoring kavramlarını; based kavramı data, internet ve monitoring kavramların; healthcare ise data, health ve internet kavramlarnı beslemiştir. Şekil 15 (b)'de anahtar kelimelerin tematik değişimi gösterilmektedir. 2001-2014 arasinda internet of things kavramının küçük bir alanı oluşturduğu görülmektedir. Kavram 2015-2017 yılları arasında kenini beslemiş ve genişlemiş 2018 2020 arasında ise oldukça büyüyen bir kavrama dönüşmüştür. Konu hakkında yapılan çalışmalarla birlikte internet of things kavramını kendisi ile beraber activity recognition, health monitoring, industrial information integration engineering, energy efficieny, m-health, healthcare ve cloud compiting kavramları beslemiştir. $\mathrm{Bu}$ kavramların internet of things kavramının altyapısını oluşturduğu söylenebilir. 6lowpan ve radiology information system 2001-2014 y1llları arasindaki anahtar kelimelerde güncel olan diğer kavramlardandır. 6low pan kendisi ile birlikte healthare ve internet of things kavramlarını beslemiştir. Radiology information system ise cloud computing ve cloud kavramlarını beslemiştir. 2018-2020 yılları arasında internet of things, sensors, werable, cloud computing, cloud ve ehealth kavramlarının güncel olduğu görülmektedir. Werable önceki yıllarda güncel olmayıp sensors kavramının kendisini beslemesi ise oluşmuştur. Şekil 15 (c)'de kaynakçayı oluşturan kelimelerin değişimi gösterilmektedir. Şekle göre 2001-2014 yılları arasinda care, internet, system ve posttraumatic-stressdisorder kavramları günceldir. Care 2015-2017 yılları arasında güncel olan interneti; internet kendisini, privacy ve technology kavramlarını, system kendisini ve information kavramını; posttraumatic-stress-disorder ise techlogies kavramını beslemiştir. 2018-2020 yılları arasında internet, access control, technology, scheme, sensor, services, activity recognition, identification, wireless, association ve exhaled breath analysis kavrammlarının ön planda olduğu görülmektedir. İnternet kavramını kendisi ile beraber big data, public health, model, privacy, system, information, technologies ve networks kavramları beslemiştir. 2018-2020 yılları arasında wireless kavramının da geliştiği görülmektedir. Kavramın altyapılarını kendisi ile beraber reduced graphene oxide oluşturmuştur. Şekil 15 (d)'de başlık kısmında yer alan kelimelerin tematik değişimi gösterilmektedir. 2001-2014 yılları arasındaki health, clinical, integration, wireless, e-health, time, internet ve parent kavramlarının güncel olduğu görülmektedir. Health kavramı yalnızca kendisini beslemiş ve 2015-2017 yılları arasında varlığını sürdürmeye devam etmiştir. Clinical care kavramını; integration ise care, system ve healthcare kavramlarını beslemiştir. Wireless kendisi ile beraber care, health, system kavramlarını beslemiştir. E-health health, health care ve wireless kavramların, time ise health, wireless ve things kavramlarını beslemiştir. Internet ve parent birlikte things kavramını beslemiştir. 2018-2020 yılları arasında based, health, iot, computing, healthcare, network ve internet kavramlarının güncel olduğu görülmektedir. Based kavramını decision, care ve system; health kavramını care, health, system, healthcare ve wireless kavramları beslemiştir. IoT kavramını care, system, wireless ve things kavramları; computing kavramını ise yalnızca system 
beslemiştir. Healthcare kavramını health, healthcare, wireless, data kavramları; network kavramını wireless ve internet kavramını things beslemiştir. Health kavramının yıllar içerisinde alandaki yerinin büyüdüğ̈̈ dikkat çekmektedir.

Şekil 15. (a) Özet Kelimelerinin Tematik Değişimi, (b) Anahtar Kelimelerin Tematik Değişimi, (c) Kaynakça Kelimelerinin Tematik Değişimi, (d) Başlık Kelimelerinin Tematik Değişimi.

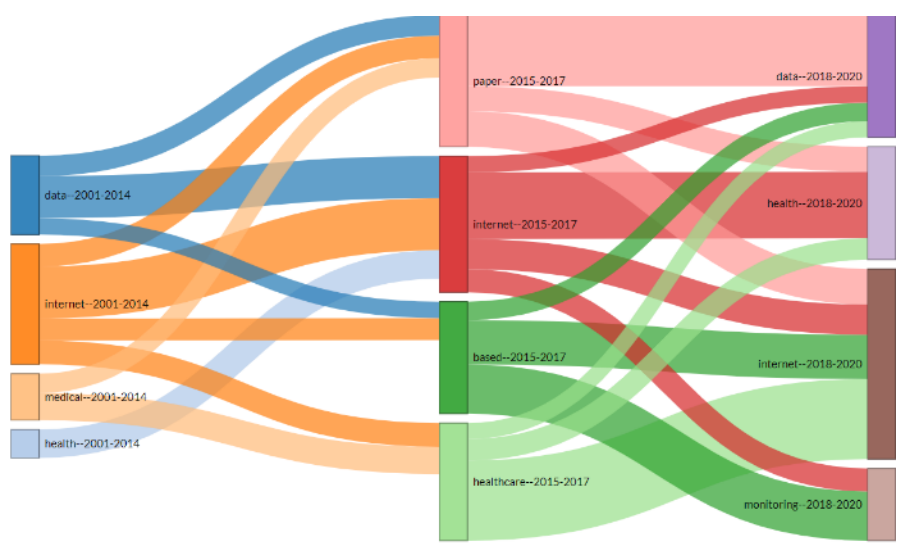

(a)

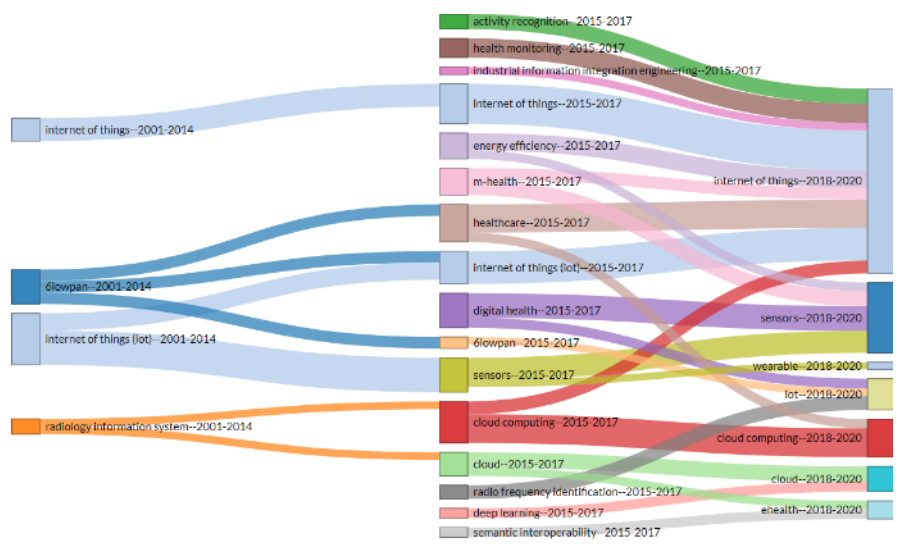

(b)

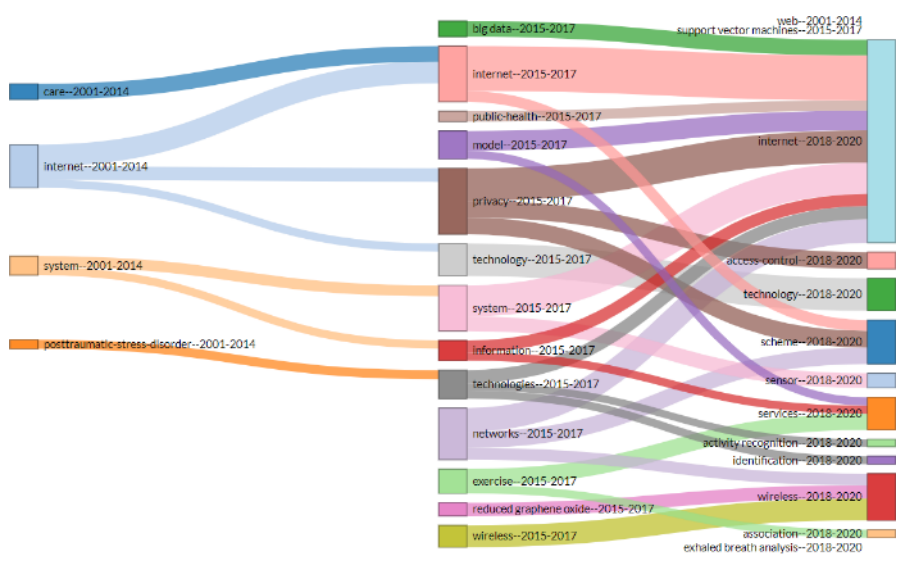

(c)

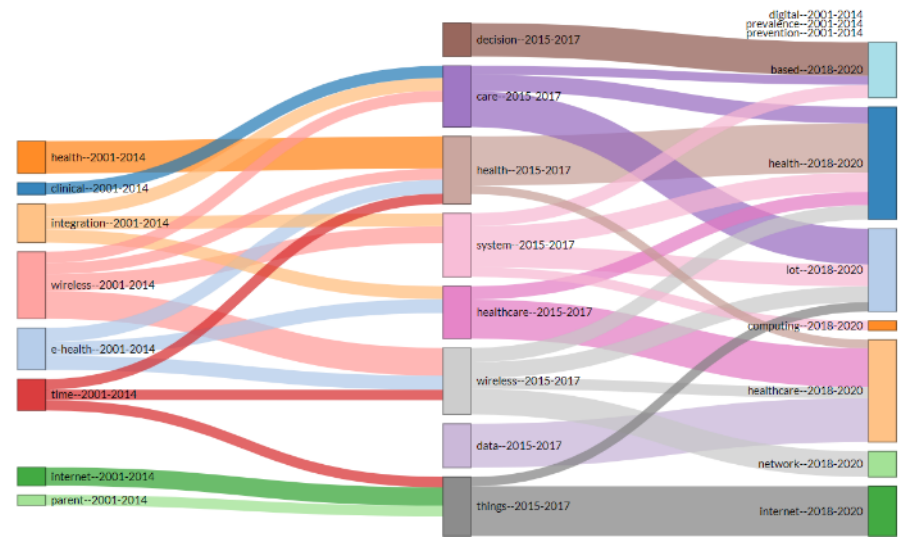

(d)

Yıllar içerisinde ön plana çıkan konular Tablo 7‘de gösterildiği gibidir. Konular belirlenirken en az 5 kez işlenmiş olması şartı aranmıştır. Anahtar kelimelerde, başlıklarda, özetlerde ve kaynakçalarda en az beş kez işlenen ilk 14 konu listelenmiş ve yılları belirtilmiştir. f ile gösterilen değerler konuların işlenme sıklığını göstermektedir. Tabloya göre anahtar kelimelerde en çok yer alan konu Internet of Things $35 \mathrm{kez}$ işlenmiştir. Başlıklarda ise en çok healthcare konusu yer almış ve 225 kere işlenmiştir. Özetlerde en çok işlenen konu 1144 işlenme sıklığı ile data olmuştur. Kaynakçada en çok yer alan konu ise internet konusudur ve $150 \mathrm{kez}$ işlenmiştir. Tabloda verilen konular en çok işlenen konulardan en az işlenen konulara göre siralanmaktadır. 2019 yılında anahtar kelimelerde healthcare 73 kere, başlıklarda Iot 87 kere, özetlerde Iot 679 kere, kaynakçalarda ise framework 39 kere işlenerek en çok işlenen kavramlar olmuşlardır.

Tablo 7. Trend Konuların Yıllara Göre Dă̆ılımı.

\begin{tabular}{c|l|c|c}
\hline & \multicolumn{1}{|c|}{ Konu } & f & Yll \\
\hline \multirow{4}{*}{ Knahtar } & Internet of Things & 129 & 2018 \\
& Healthcare & 73 & 2019 \\
& Internet of Things (Iot) & 53 & 2018 \\
& Iot & 43 & 2019 \\
& Security & 35 & 2018 \\
& Cloud Computing & 35 & 2018 \\
& Privacy & 32 & 2018 \\
& Fog Computing & 21 & 2019 \\
& Smart Healthcare & 17 & 2019 \\
& Internet of & 15 & 2019 \\
& Authenticatıon & 11 & 2017 \\
& Health Monitoring & 11 & 2017 \\
& Digital Health & 7 & 2017 \\
& Internet & 6 & 2016 \\
\hline & Healthcare & 225 & 2018 \\
& Health & 201 & 2018 \\
& Internet & 105 & 2018 \\
& Monitoring & 104 & 2018 \\
& System & 104 & 2018 \\
& Things & 104 & 2018 \\
& Iot & 87 & 2019 \\
& Computing & 29 & 2019 \\
& Mobile & 27 & 2019 \\
& Environment & 22 & 2019 \\
& Review & 2019 \\
& Design & 2017 \\
& & &
\end{tabular}




\begin{tabular}{|c|c|c|c|}
\hline & $\begin{array}{l}\text { Clinical } \\
\text { Body }\end{array}$ & $\begin{array}{l}11 \\
11\end{array}$ & $\begin{array}{l}2017 \\
2017\end{array}$ \\
\hline \multirow{14}{*}{ Özet } & Data & 1144 & 2018 \\
\hline & Health & 920 & 2018 \\
\hline & Healthcare & 900 & 2018 \\
\hline & Iot & 679 & 2019 \\
\hline & System & 534 & 2018 \\
\hline & Internet & 501 & 2018 \\
\hline & Security & 269 & 2019 \\
\hline & Network & 229 & 2019 \\
\hline & Privacy & 216 & 2019 \\
\hline & Study & 167 & 2019 \\
\hline & Support & 83 & 2017 \\
\hline & Node & 29 & 2017 \\
\hline & Flexible & 28 & 2017 \\
\hline & Prevention & 28 & 2017 \\
\hline \multirow{14}{*}{ Kaynakça } & Internet & 150 & 2018 \\
\hline & Things & 106 & 2018 \\
\hline & System & 61 & 2018 \\
\hline & Care & 44 & 2018 \\
\hline & Framework & 39 & 2019 \\
\hline & Cloud & 28 & 2018 \\
\hline & Challenges & 27 & 2019 \\
\hline & Iot & 27 & 2019 \\
\hline & Big Data & 25 & 2019 \\
\hline & Security & 24 & 2019 \\
\hline & Wireless & 13 & 2017 \\
\hline & Sensor Networks & 12 & 2017 \\
\hline & Information-Technology & 8 & 2017 \\
\hline & Service & 6 & 2017 \\
\hline
\end{tabular}

Özetlerin kelime haritası incelendiğinde kırmızı ve mavi renk ile gösterilen iki oluşumun yer aldığı görülmektedir. $\mathrm{Bu}$ oluşumlarda dağınık halde olan konu belli başlıklar altında toplanmıştır. Mavi renk ile gösterilen yapı sensor ve energy kavramlarından oluşmuştur. Küme IoT'de sensörler ve enerji konularının işlendiği çalışmalar şeklinde ifade edilebilir. Kırmızı renk ile gösterilen yapı ise daha geniş sınırları olan ve iki alt kümeden oluşan bir yapıdır. Birinci kümeyi scheme, privacy ve access kavramları oluşturmaktadır. Bu alt küme IoT'de erişimde gizlilik ve güvenlik sorunları olarak adlandırılabilir. İkinci alt kümeyi ise cloud, users, patient, analysis, computing, propose, service, mobil, study, environment, applications, network, architecture, framework, monitoring gibi birçok kavram oluşturmaktadır. Küme IoT'de sağlığın izlenmesi uygulamalarında kablosuz a $\breve{g}$ performansları ve önerilen mimariler şeklinde ifade edilebilir. (Şekil 16, Şekil 17 ve Şekil 18 correspondence analizine göre yapılmıştır.)

\section{Şekil 16. Özetlerin Kelime Haritası.}

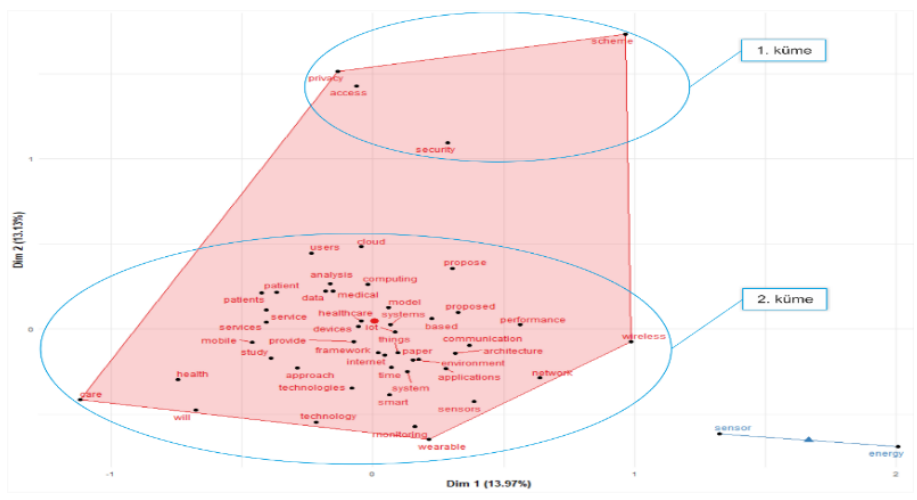

Anahtar kelimelerin haritası incelendiğinde mavi renkli kümeyi internet kelimesinin oluşturduğu görülmektedir. Küme IoT tabanlı sağlık hizmetlerinin araştırılmasında internet kullanımı olarak ifade edilebilir. Kırmızı renkli küme ise iki alt kümede incelenebilmektedir. Kümelerden ilkini privacy preserving ve internet of things kavramları oluşturmaktadır. Küme IoT'de gizliliğin korunması olarak ifade edilebilir. İkinci kümeyi ise activity recognition, data, wearable sensors, health, cloud computing, big data, smart home, healthcare, ambient assisted living, privacy, smart city, internet of medical things, monitoring, fog computing gibi kavramlar oluşturmaktadır. $\mathrm{Bu}$ geniş küme giyilebilir teknolojiler aracılığı ile etkinlik tanıma, sağlık hizmetlerinde bulut ve sis bilişim olarak ifade edilebilir.

Şekil 17. Anahtar Kelimelerin Haritast.

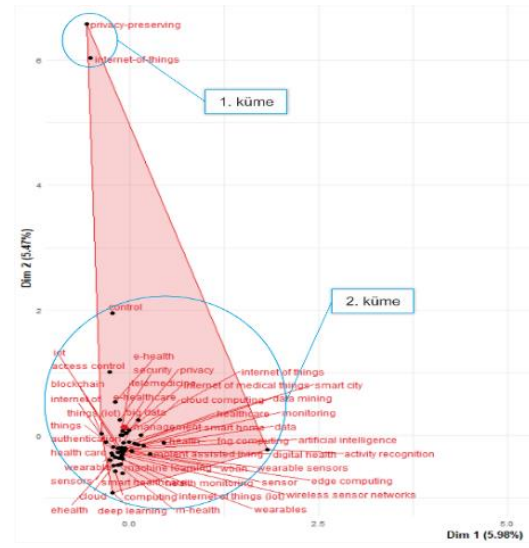

Başlıkların oluşturduğu küme incelendiğinde mavi ve kırmızı renkli iki oluşumun bulunduğu görülmektedir. Kırmızı küme access, control, e-health, authentication, scheme, privacy, iotbased, security, services, medical, efficient, secure, architecture kavramlarının yer aldığı kümedir. Küme IoT tabanlı e-sağlık uygulamalarında erişimin denetimi, hizmet sunumunda güvenlik ve gizliliğin doğrulanması olarak ifade edilebilir. Mavi küme ise monitoring, wearable, wireless, network, real-time, sensor, analysis, sensors, remote kavramlarının yer aldığı kümedir. Mavi küme giyilebilir sensörler aracılığı ile gerçek zamanlı izleme olarak ifade edilebilir.

\section{Şekil 18. Başlıkların Kelime Haritası.}

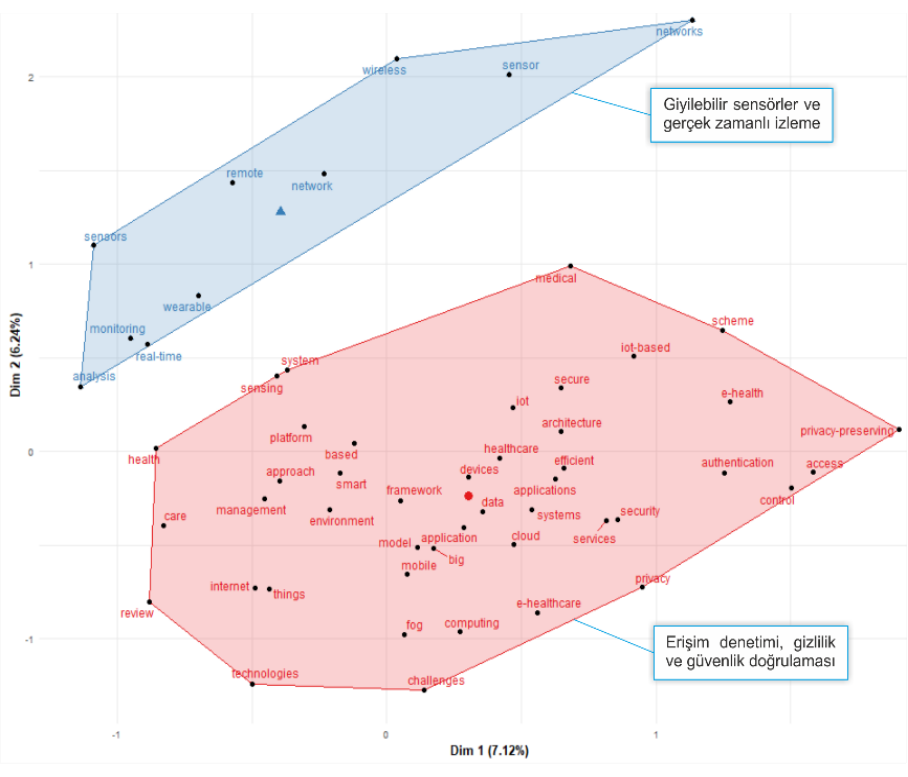


Özetlerde yer alan kelimelerin oluşturduğu küme incelendiğinde kırmızı ve mavi ile gösterilen iki oluşumun meydana geldiği görülmektedir. Kırmızı küme daha geniştir ve kendi içerisinde yedi alt kümeye ayrılabilmektedir. İlk küme technologies, technology, study, will ve care kavramlarının oluşturduğu kümedir ve küme sağlık bakım teknolojilerinin geleceği olarak ifade edilebilir. İkinci küme mobile, iot, computing, patient, healthcare, services, health, service, patients kavramlarından oluşmaktadır bu küme de mobil sağlık hizmetleri şeklide ifade edilebilir. Üçüncü küme medical, users, cloud, data ve security kavramlarından oluşmaktadır. Küme bulut destekli medikal uygulamalar ve kullanıcı verilerinin güvenliği şeklinde ifade edilebilir. Dördüncü küme sensor, energy, wireless, performance, network ve propose kavramlarından oluşmaktadır küme kablosuz ă̆ ve sensörlerin enerji performansı şeklinde ifade edilebilir. Beşinci küme ise approach, framework, devices, smart, model, systems, system, analysis, architecture, based, proposed kavramlarından oluşmaktadır. Beşinci küme IoT tabanlı akıllı cihazlarda önerilen sistem ve mimariler olarak ifade edilebilir. Altıncı küme things, environment, provide, applications, internet, werable kavramlarından oluşmaktadır. Küme IoT tabanlı ortama duyarlı giyilebilir teknolojilerin geliştirilmesi şeklinde ifade edilebilir. Son küme olan yedinci küme ise time paper, sensors, monitoring, communication kavramlarından oluşmaktadır. Küme sensörler arası iletişim ve sensörlerin eş anlı izlenmesi şeklinde ifade edilebilir. Mavi küme ise privacy, Access ve sheme kavramlarından oluşmaktadır. Küme erişimde gizliliğin sağlanmasına yönelik şemalar olarak ifade edilebilir. (Şekil 19, Şekil 20, Şekil 21 ve Şekil 22 multidimensional scaling analizine göre yapılmıştır.)

\section{Şekil 19. Özetlerin Kelime Haritası.}

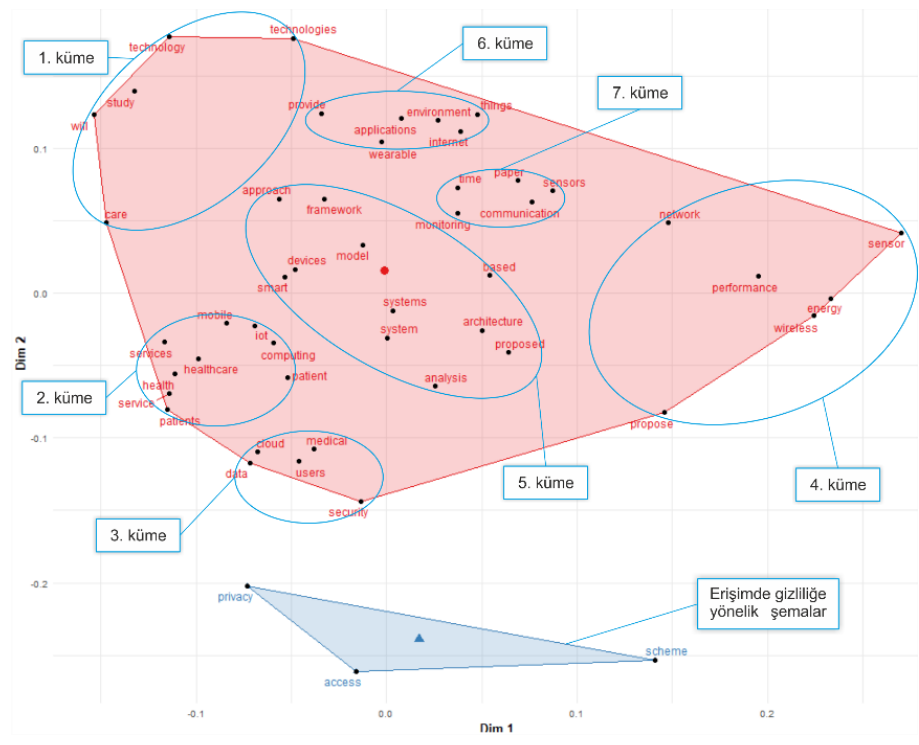

Anahtar kelimelerde yer alan kavramların kümelenmeleri incelendiğinde yine geniş bir kırmızı yapı ile mavi yap1 oluşmuştur. Mavi kümeyi oluşturan kavramlar things, thing (iot), internet of kavramlarıdır. Küme nesnelerin interneti şeklinde ifade edilebilir. Kırmızı küme ise sekiz alt kümede ifade edilebilir. Kırmızı yapıyı oluştıran birinci kümede smart home, telemedicine ve ambient assisted living kavramları yer almaktadır. Birinci küme ortam destekli sağlık hizmet bakımı olarak ifade edilebilir. Bu kümede daha çok kişisel sağlık hizmetlerinde kullanılan akıllı evler, ortama duyarlı cihazlar ve teletıp uygulamalarının yer aldığ söylenebilir. İkinci küme activity recognition, health monitoring, smart city, sensors, smart healthcare, wearable, wearables, wireless sensor networks kavramlarından oluşmaktadır. Küme sağlığın izlenmesinde giyilebilir kablosuz ağ teknolojileri ve sensörler aracılığı ile davranış tanımlama şeklinde ifade edilebilir. Üçüncü küme data mining, edge computing ve e-health kavramlarından oluşmaktadır. Küme sağlık hizmetlerinde veri madenciliği ve verilerin depolama hesaplamaları şeklinde ifade edilebilir. Dördüncü küme privacy-preserving, healthcare, management, internet of things ve control kavramlarından oluşmaktadır. Küme sağlık hizmetleri yönetimi ve IoT uygulamalarında gizliliğin kontrolü şeklinde ifade edilebilir. Beşinci küme internet of medical things, cloud computing, access control, fog computing, internet of things, internet, security, authentication, e-healthcare, iot, internet of things (iot), privacy, deep learning kavramlarından oluşmaktadır. Küme medikal nesnelerin internetinde bulut ve sis bilişimlerde erişimin kontrolü ve gizliliğin sağlanması amacı ile kimlik doğrulama uygulamaları şeklinde ifade edilebilir. Altıncı küme big data, block chain, wearable sensors kavramlarından oluşmaktadır. Küme giyilebilir teknolojilerde elde edilen verilerin üçüncü tarafların erişiminin engellenmesi şeklinde ifade edilebilir. Yedinci küme computing, cloud, wban ve monitoring kavramlarından oluşmaktadır. Küme giyilebilir teknolojilerde bulut bilişimi hesaplamaları şeklinde ifade edilebilir. Sekizinci küme machine learning, data, sensor, artifical intelligence ve digital health kavramlarından oluşmaktadır. Küme dijital sağlık uygulamalarında makine öğrenmesi ve yapay zeka uygulamaları şeklinde ifade edilebilir.

\section{Şekil 20. Anahtar Kelimelerin Haritası.}

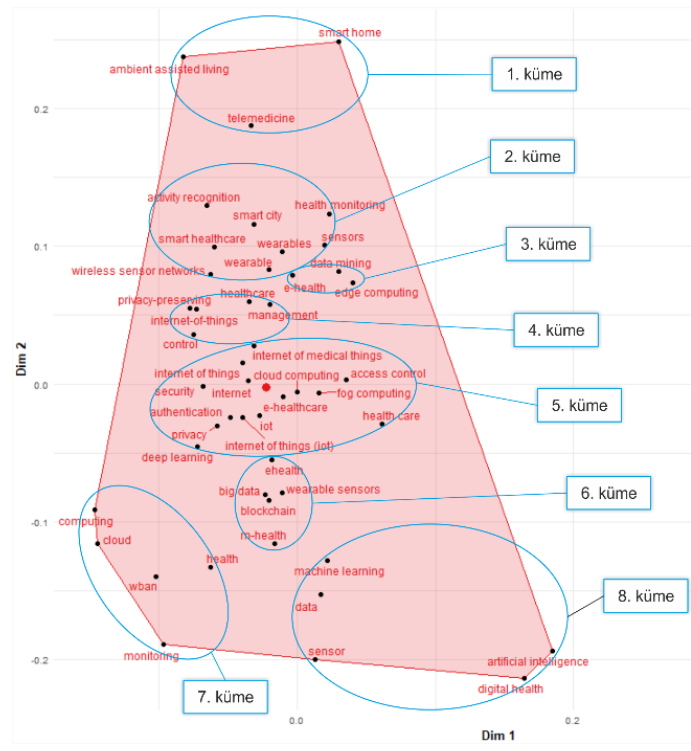

Keywords plus kısmında yer alan kelimelerin oluşturduğu yapıda ise yine kırmızı geniş bir küme yer almaktadır. Fakat mavi yapının sınırlarının geliştiği görülmektedir. Mavi kümede integration, monitoring system, service ve fog kavramları yer almaktadır. Küme sağlık izleme sistemlerinin entegrasyonu ve sis bilişim şeklinde ifade edilebilir. Kırmızı küme ise kendisini oluşturan iki alt kümeye sahiptir. Birinci kümeyi oluşturan kavramlar efficient, attribute-based encryption, authentication, user authentication, secure, protocol, acces, issues, devices, sensor networks, networks kavramlarıdır. Küme IoT tabanlı cihaz ve ağların verimliliği ile erişimde güvenlik şeklinde ifade edilebilir. İkinci küme ise platform, classification, systems, implementation, sensor, system, iot, big data, information, activity recognition, challenges, architecture, sensors, model, energy, diagnosis, prediction, care, services, things, analytics, information-technology, algorithm, internet, technology, 
technologies, optimization, framework kavramlarının yer aldığı kümedir. Küme IoT aracılığı ile hastalığın tahmin edilmesi, teşhis ve tedavisinin yapılması ile bu hizmetlere yönelik geliştirilen sistemlerin mimarisi şeklinde ifade edilebilir.

Şekil 21. Kaynakçaların Kelime Haritası.

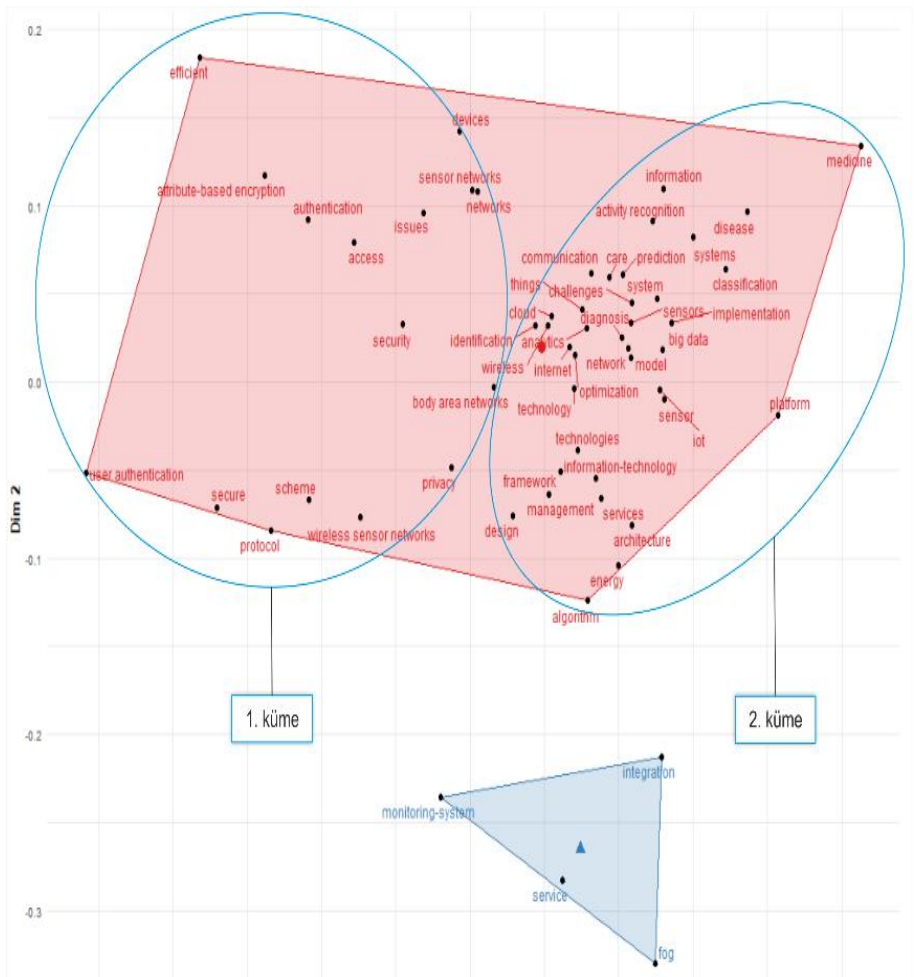

$\operatorname{Dim} 1$

Başlıklarda yer alan kavramların kümelenmeleri incelendiğinde yine geniş bir kırmızı yapı ile mavi yap1 oluşmuştur. Mavi kümeyi oluşturan kavramlar access ve control kavramlarıdır. Küme IoT tabanlı uygulamalarda erişimin kontrolü şeklinde ifade edilebilir. Kırmızı yapı ise kendisini oluşturan alt kümelerden meydana gelmiştir. Birinci kümede networks, wireless, sensor, medical, remote, sensors, real time, wearable, monitoring, analysis, network, iot-based kavramları ye almaktadır. $\mathrm{Bu}$ küme medikal uygulamalarda IoT tabanlı sensörlerin uzaktan ve eş zamanlı izlenmesi şeklinde ifade edilebilir. İkinci küme authentication, privacy-preserving, efficient, e-health, security, services, privacy, e-healthcare, cloud kavramlarından oluşmaktadır. Küme e-sağlık uygulamalarında gizliliğin korunması şeklinde ifade edilebilir. Üçüncü kümede healthcare, system, iot, health, architecture, based, platform, data, applications, systems, smart, framework, management, approach, things, care ve internet kavramları yer almaktadır. Küme IoT tabanlı sağlık uygulamalarının mimari kısmını içermektedir. Küme bulut destekli uygulamalar, bu uygulamaların mimarisi, zorlukları ve yönetimi şeklinde ifade edilebilir. Dördüncü küme ise fog ve computing kavramlarından oluşmaktadır. Küme IoT uygulamalarındaki sis hesaplamaları şeklinde ifade edilebilir.
Şekil 22. Başlıkların Kelime Haritası.

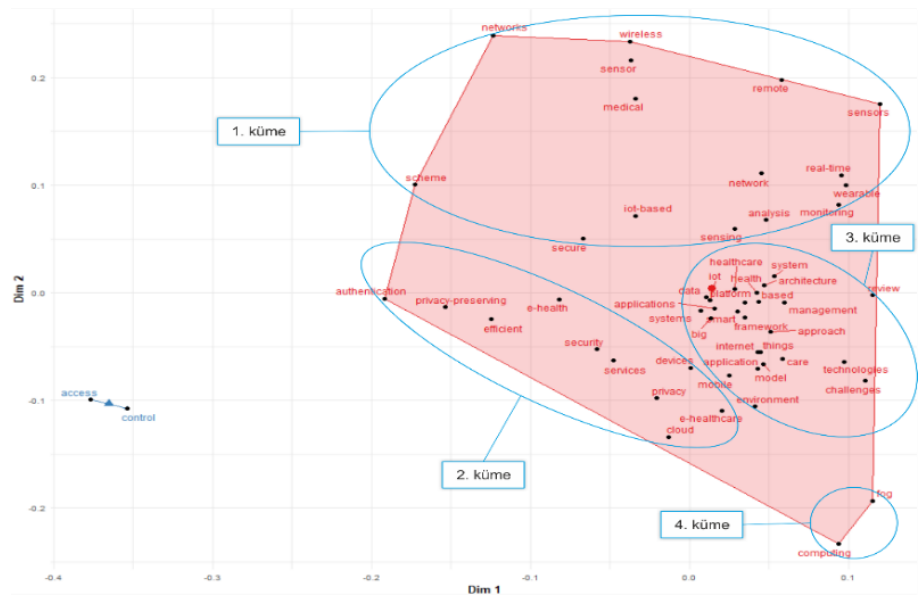

Anahtar kelimelerde yer alan temel kavramların kümelenmeleri incelendiğinde kırmızı yapının geniş sınırları olduğu görülmektedir. Yapıyı oluşturan çeşitli alt kümeler mevcuttur. Birinci kümeyi oluşturan kavramlar $\mathrm{m}$ health, computing ve cloud kavramlarıdır ve küme bulut destekli mobil sağlık uygulamaları şeklinde ifade edilebilir. İkinci kümeyi oluşturan kavramlar wban, monitoring, privacy, health, authentication, security, internet of things ve blockchain kavramlarıdır. Küme IoT tabanlı giyilebilir teknolojilerin izlenmesinde gizlilik, güvenlik ve kimlik doğrulama şeklinde ifade edilebilir. Üçüncü küme ise diğer iki kümeye göre daha geniş kavramları içerisinde barındırmaktadır. Kümeyi oluşturan kavramlar access control, big data, deep learning, fog computing, digital health, artifical intelligence, smart healthcare, healthcare, wearable, smart home, ambient assisted living, telemedicine, ectivity recognition management, data mining kavramlarıdır. Küme akıllı sağlıkta veri erişiminin kontrolü ve kişiselleştirilmiş sağlık hizmetleri şeklinde ifade edilebilir. Mavi küme ise things iot, internet of ve things kavramlarından oluşmakta ve nesnelerin internetini ifade etmektedir. (Şekil 23, Şekil 24 ve Şekil 25 multiple correspondence analizine göre yapılmıştır.)

Şekil 23. Anahtar Kelimelerin Haritası.
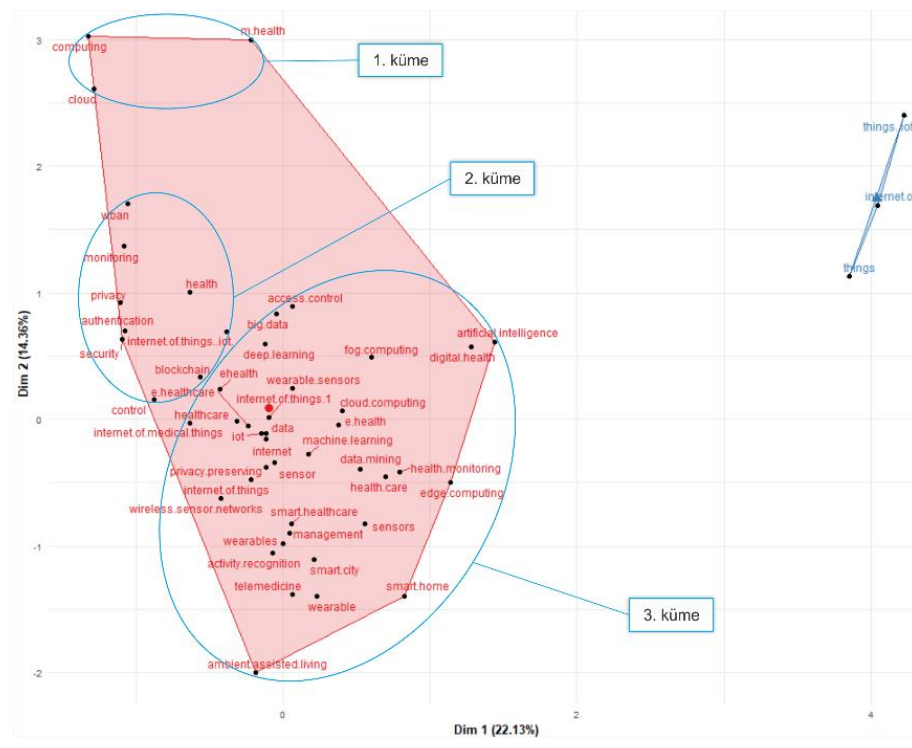

Kaynakça kısmında yer alan temel kavramların kümelenmeleri incelendiğinde kırmızı yapının yine geniş sınırları olduğu görülmektedir. Mavi yapıyı oluşturan kavramlar fog, integration, architecture ve implementation kavramlarıdır. Küme 
IoT'de bulut uygulamalarının mimarisi ve entegresyonu olarak tanımlanabilir. Kırmızı küme çeşitli alt kümelerden oluşmaktadır. Birinci küme user authentication, attribute based encryption, scheme, efficient, secure, monitoring system, access, wireless sensor networks, service, security, body area networks ve authentication kavramlarından oluşmaktadır. Küme giyilebilir teknolojiler ve izleme sistemlerinde verimlilik, gizlilik ve kimlik doğrulama uygulamaları şeklinde ifade edilebilir. İkinci küme wireless, sensor networks, optimization, information technology, communication, prediction, technology ve systems kavramlarından oluşmaktadır. Kablosuz ağların optimizasyonu ve tahmin sistemleri şeklinde ifade edilebilir. Üçüncü kümeyi oluşturan kavramlar design, networks, issues, algorithm, identification, analytics, energy, devices, activity recognition, sensor, sensors, system, model, diagnosis ve classification kavramlarını içermektedir. Küme sensörler aracılığı ile etkinlik tanıma, elde edilen verilerin tanımlanması, sınıflandırılması ve veri algoritmalarının analizi şeklinde ifade edilebilir. Dördüncü küme big data, medicine, information, disease, internet, technologies, things, kavramlarından oluşmaktadır. Küme sağlık ve bilgi teknolojilerinde IoT tabanlı uygulamalar şeklinde ifade edilebilir. Beşinci küme iot, platform, challenges, services, framework, cloud kavramlarından oluşmaktadır. Küme bulut teknolojilerindeki zorluklar şeklinde ifade edilebilir.

\section{Şekil 24. Kaynakçaların Kelime Haritası.}

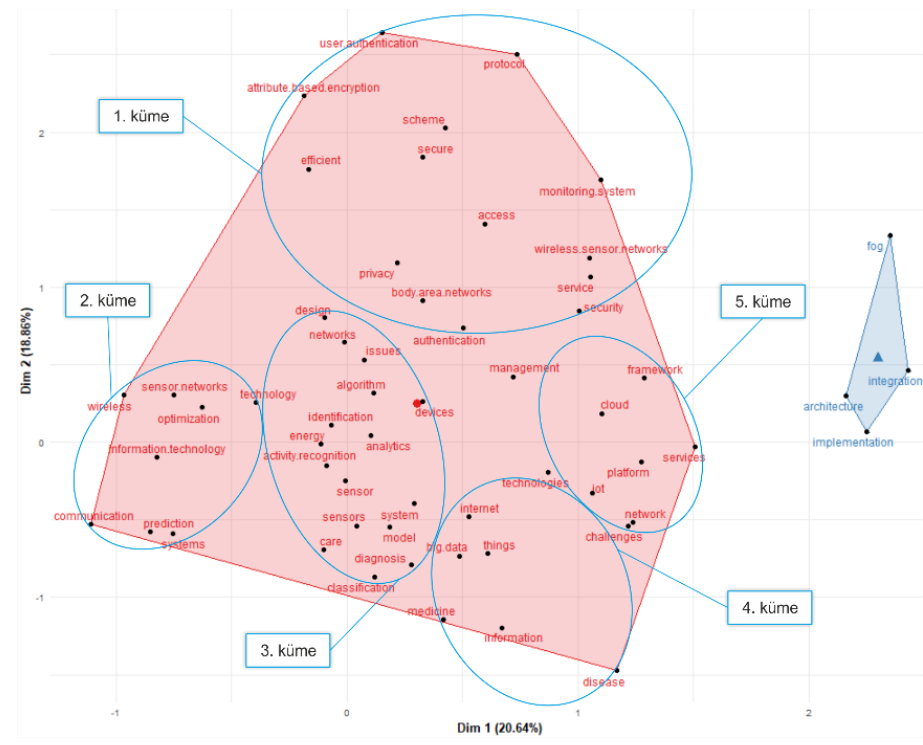

Başlık kelimelerinde yer alan temel kavramların kümelenmeleri incelendiğinde kırmızı yapının içerisinde alt kümeleri barındırdığı görülmektedir. Mavi yapı ise wireless, sensor, medical ve networks kavramlarından oluşmuştur. Küme sağlıkta kablosuz ağlar ve sensörler şeklinde ifade edilebilir. Kırmızı yapıyı oluşturan birinci alt küme ise access, privacy preserving, scheme, iot based, control, authentication, privacy, security, services, e heath ve secure kavramlarından oluşmaktadır. Küme IoT tabanlı uygulamalarda erişimin kontrol edilmesi ve gizliliğin sağlanması şeklinde ifade edilebilir. İkinci küme framework, devices, data, healthcare, applications, efficient, iot, architecture, system, services, platform, mobile, model, e healthcare kavramlarından oluşmaktadır. Küme akıllı sağlık sistemlerinin mimarisi ve verimliliği şeklinde ifade edilebilir. Üçüncü küme environment, management, based, approach, system, analysis, sensing, network, remote, sensors, wearable, real time, monitoring, health ve care kavramlarından oluşmaktadır. Küme sağlık bakımında giyilebilir teknolojiler ile eş anlı ve uzaktan izleme şeklinde ifade edilebilir. Dördüncü küme computing, fog, technologies, things ve internet kavramlarından oluşmaktadır. Küme sis ve bulut bilişim teknolojilerinin zorlukları şeklinde ifade edilebilir.

\section{Şekil 25. Başlıkların Kelime Haritası.}

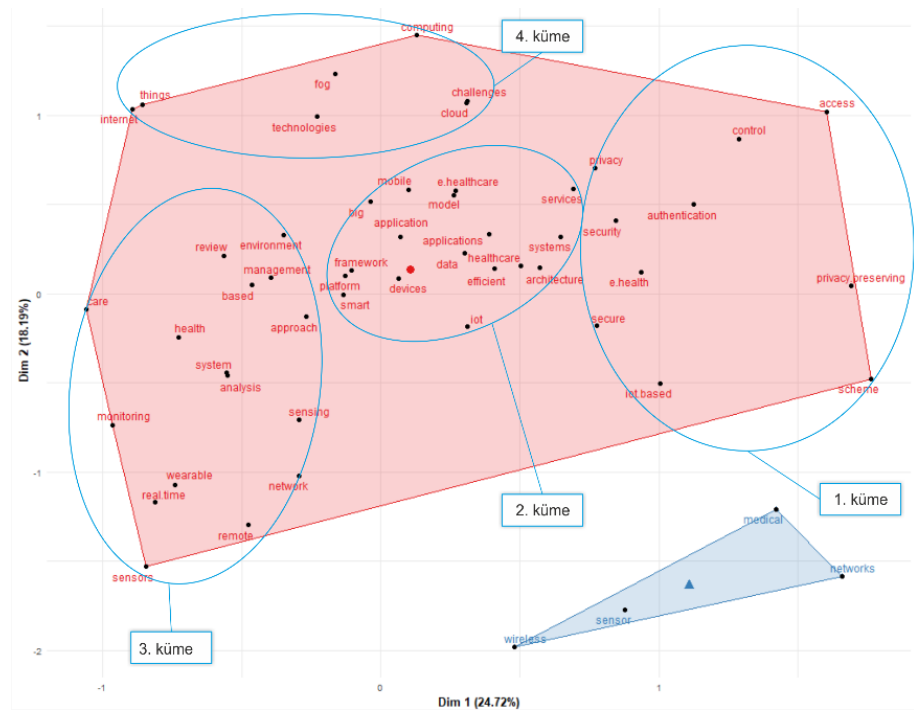

Çalışmanın veri setini oluşturan makaleler VOSviewer programı ile analiz edilerek en az $10 \mathrm{kez}$ kullanılan kelimeler belirlenmiştir. Kelimeler standardize edilerek kullanım sıklığına ve dahil oldukları konuyu göre gruplandırılmıştır. Şekil 26 (a)'da kelimeler sunburst grafiği yardımı ile 26 (b)'de radial grafik ile görselleştirilmiştir. Şekilde büyük puntolar ile gösterilen kelimeler en sık kullanılan kelimelerdir. Yeşil renk ile gösterilen küme sağlık hizmetlerinde IoT uygulamaları literatüründe araştırma alanlarının incelendiği çalışmalar şeklinde ifade edilebilmektedir. Firsatlar, zorluklar gibi bileşenlere ait çalışmaların bu grubu oluşturduğu söylenebilir. Bu kümelemede en çok kullanılan sözcükler sırası ile research, field, year, area, review, population, component ve opportunity sözcükleridir. Kahverengi ile gösterilen küme ise verilerin aktarımı esnasında uygulanan kuralların ve protokollerin gizliliklerinin, verimliliklerinin ve güvenliklerinin belirlenmesine yönelik çalışmalardan oluşmaktadır. Kahverengi kümede en çok kullanılan ilk 5 sözcük sırası ile privacy, performance, security, scheme ve protocol sözcükleridir. Mavi renk ile gösterilen küme hareket sinyallerinin doğruluğu ve çeşitli parametrelerin deneysel ölçümlerine dayanan çalışmaların olușturduğu kümedir. Akıllı sensörlerin sağlık alanında kullanılarak çeşitli girdileri (hataların izlenmesi, harekerleri, tıbbi verileri) sinyallere dönüştürmesi ile ilgili yapılan deneysel çalışmalar bu kümede yer almaktadır. Mavi kümede en çok kullanılan ilk 5 sözcük sırası ile accuracy, activity, signal, experimental result ve parameter sözcükleridir. Sarı renk ile gösterilen küme daha çok iletişim teknolojilerindeki gelişmelerin ve bu alanda strandart etki büyüklüklerinin yer aldığg çalışmalardan oluşmaktadır. Sarı kümede en çok kullanılan ilk 5 sözcük sırası ile communication technology, standard, effect, range ve advance sözcükleridir. Makaleler herhangi bir alan veya konu ayırımı yapılmadan değerlendirildiğinde ise en çok kullanılan ilk 10 kavram research, privacy, performance, security, scheme, assuracy, protocol, signal activity ve field kavramlarıdır. $\mathrm{Bu}$ kavramların sıklıkla kullanılıyor oluşu makalelerde işlenen konular hakkında ipucu vermektedir. Research her ne kadar geniş kapsamı olan bir kelime olsa da. Privacy, performance, security gibi kavramlar sağlık hizmetlerinde IoT uygulamalarında gizliliğin, performansın ve güvenliğin esasında sıklıkla 
tartışıldığını göstermektedir. Bununla birlikte söz konusu kavramlar kümeleri oluşturan konulara da işaret etmektedir.

\section{Şekil 26. (a) Sunburst Grafiği, (b) Radial Grafik.}

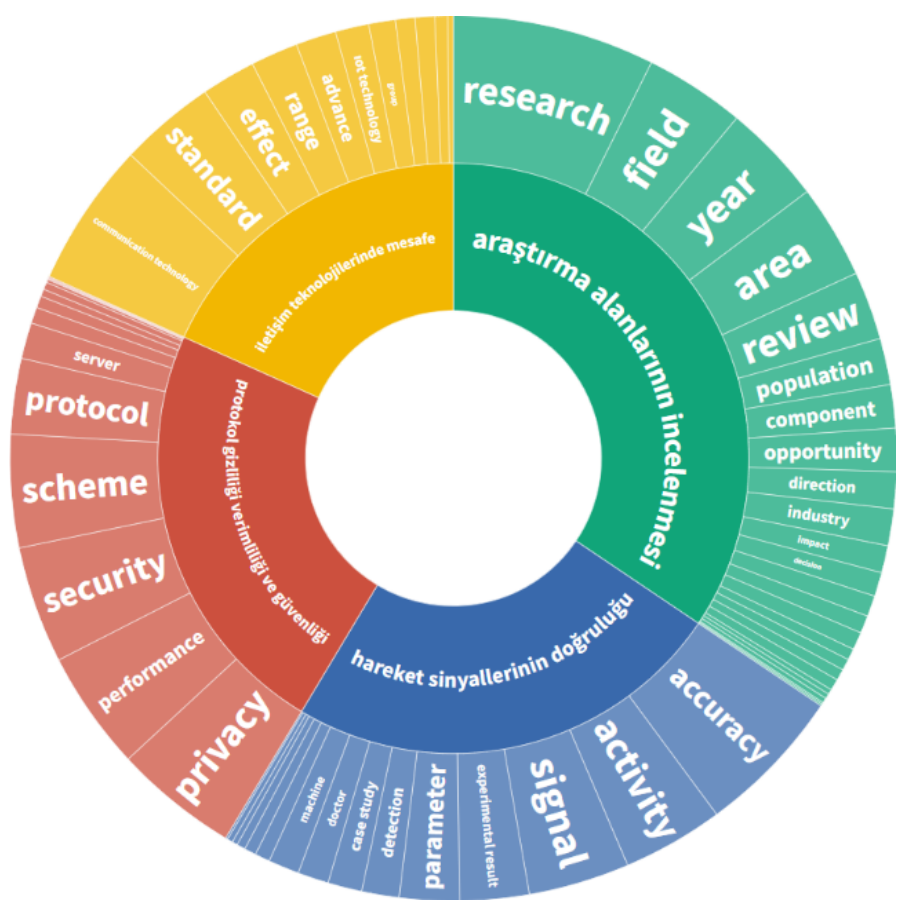

(a)

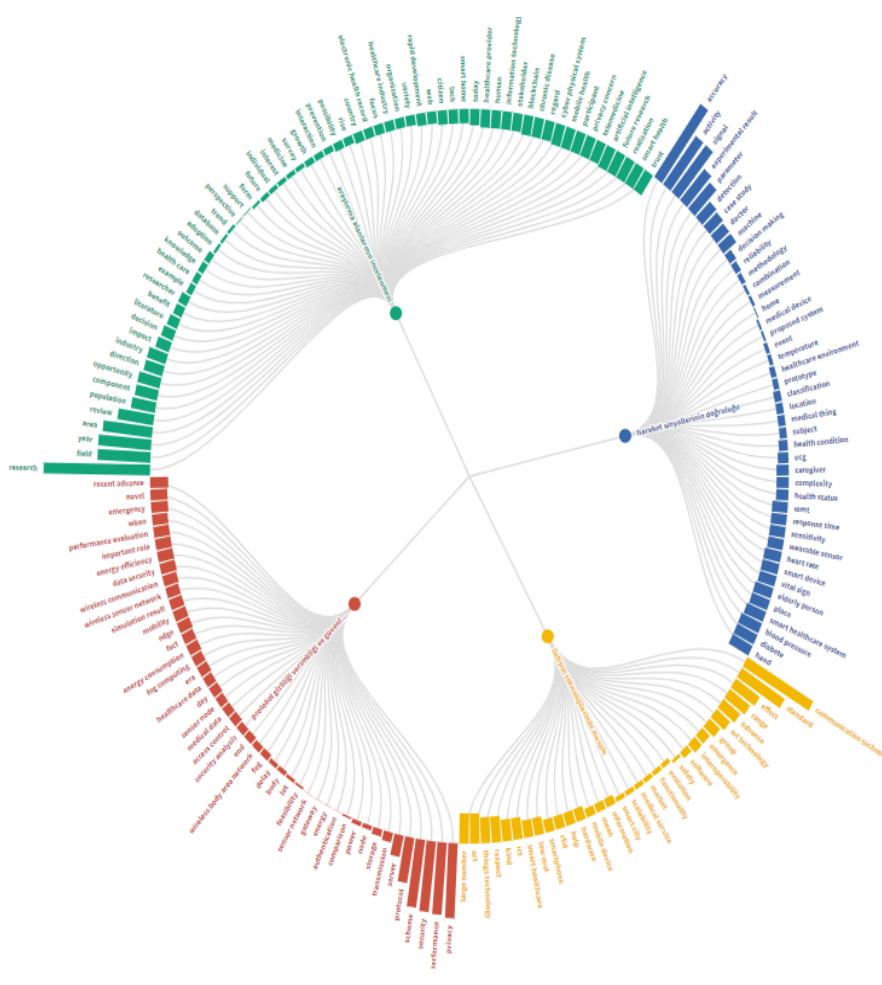

(b)

\subsection{Tartışma}

Günümüzde özellikle Japonya, ABD ve Avrupa'da evde tedavi gören hasta sayısı ile yaşlı nüfusun artması sebebiyle sağlık hizmet sunum sürecine IoT'deki gelişmelerle birlikte akıllı telefonlar, gömülü cihazlar gibi ekipmanlar dahil olmuştur (Mano vd., 2016). Bunun yanı sıra hastalık tahmin ve teşhis sistemleri (P.
M. Kumar, Lokesh, Varatharajan, Babu, \& Parthasarathy, 2018), akıllı kişisel asistanlar (Santos vd., 2016b), sağlık uygulamalarında güvenliğin sağlamasında büyük verinin yeri (Suciu vd., 2015) ve aynı zamanda büyük verilerin güvenilir bir şekilde işlenmesinin sağlanması (Nepal, Ranjan, \& Choo, 2015) özellikle tartışılan konular arasındadır. Ayrıca sağlık hizmetlerindeki IoT tabanlı teknikler de incelenmiştir (Rodrigues, JJPC Segundo vd., 2018) ve sağlık alanında IoT uygulamalarına ait çalışmalar incelendiğinde sağlık sektöründeki IoT uygulamalarının özetlendiği ve gelecekteki araştırmalara yön verilmeye çalışıldığı görülmektedir. Gelecekteki iyileştirmeler için kendi kendine öğrenme ve kendini geliştirme, donanım, standardizasyon, gizlilik ve güvenlik konularına yönelik çalışmalar yapılmış (Yin vd., 2016) sağlık sisteminde verilerin aktarılması ile ilgili güvenlik endişelerinin giderilmesi için blockchain tabanlı akıllı sözleşmeler kullanılması önerilmiştir (Griggs vd., 2018). Bununla birlikte IoT özellikli bir sağlık sisteminde günlük yaşam verilerinin geçerliliğinin arttırılması için fiziksel etkinlik bir hedef olarak ele alınmıştır (P. Yang vd., 2018). IoT tabanlı mobil ağ geçidi çözümleri önerilmiş ve bu ağ geçidi ile hastanın yeri, kalp atışı ve olası düşme riski hakkında olarak bilgi toplanmıştır. Toplanan bilgilerin gerçek zamanlı olarak bir akıllı kişisel asistana iletilmesi sağlanmıştır. Bu sayede çeşitli sensörler aracılığı ile kişisel asistanı kullanan bakıcılara hastalarının sağlık durumlarını her zaman ve her yerde kontrol etme firsatı sunulmuştur (Santos vd., 2016b).

Yakın tarihli çalışmalar incelendiğinde ise sağlık hizmetlerinde sensör bulutunda anormalliğin algılanması (Kumar Dwivedi, Kumar, \& Buyya, 2021), IoT tabanlı sağlık hizmetlerinde reçete analizi gibi uygulamalar için kelime benzerliği ölçüm yöntemi (Zhang vd., 2021), IoT tabanlı akıllı hastanelerde tasarımı etkileyen faktörlerin analizi (Uslu, Çalış, Okay, \& Dursun, 2020), solunum hastalıklarında sağlık hizmeti internetinin tasarımı ve uygulanması (Tsai vd., 2020), klinik deneylerin iyileştirilmesinde ileri teknolojilerin uygulanmasına yönelik sistematik haritalama (Ngayua, He, \& Boahene, 2020), hastalığın erken teşhisi için güvenli uzaktan sağlık izleme modeli (Akhbarifar, Javadi, Rahmani, \& Hosseinzadeh, 2020), kontrol edilemeyen gizlilik hesaplamalarının algılanan kontrol ve ahlaki hususların IoT tabanlı sağlık cihazlarının kullanımına etkisi (Princi \& Kramer, 2020), IoT'nin sağlık hizmetlerinde kullanımının etkisi ve sonuçları (Kelly, Campbell, \& Scuffham, 2020), doktorların Covid-19 salgını sırasında Irak'ta iot tabanlı ağlık cihazlarını kullanma niyetlerinin incelenmesi (Alhasan vd., 2020), C-ortalamalar algoritması kullanılarak sağlık hizmetlerinde büyük verilerin kümelenmesi (Purandhar, Ayyasamy, \& Saravanakumar, 2020) konularının araştırıldığ sonucuna varılmıştır. Konular göz önünde bulundurulduğunda ayrıntıların ele alınmaya başlandığı görülmektedir. Bununla birlikte IoT firsat olarak görülse de zorlukları yakın tarihli çalışmalarda incelenmeye başlanmıştır.

IoT alanında yapılan bibliometrik analizler incelendiğinde g1da güvenliğinde IoT (Bouzembrak, Klüche, Gavai, \& Marvin, 2019), tıp alanında IoT (Sadoughi, Behmanesh, \& Sayfouri, 2020), Hindistan'daki mobil sağlık hizmetleri ve uygulamaları (Pai \& Alathur, 2021), Endonezya'daki sağlık bilgi sistemlerinin araştırma durumu (Madjido, Espressivo, Maula, Fuad, \& Hasanbasri, 2019) gibi konularda bibliyometrik analizlerin yapıldığı görülmektedir. Yapılan çalışmalar alana büyük katkı sağlamakla beraber bu çalışmanın diğer çalışmalardan farkı sağlık hizmetlerinde IoT uygulamalarını bir bütün olarak ele alması ve konu hakkında genel durumun ortaya konulmaya çalışılmasıdır. 


\section{Sonuç}

Sağlık hizmetlerinde IoT uygulamalarına ait araştırmalar oldukça güncel olmasına rağmen geniş ve disiplinlerarası bir alana dağılmış durumdadır. Alanın disiplinlerarası oluşu çok sayıda araştırma yapılmasına olanak sağlamaktadır özellikle 2014 yılı itibari ile araştırmaların sayısı ciddi bir biçimde yükseliş göstermektedir. Bu durum konu hakkında okuma yapmak isteyen araştırmacı ve karar vericilerin karşısında olumsuz bir durum yaratmaktadır. Çünkü okuma ve ön araştırma esnasında geniş bir bilgi yığını karşısında okuyucu kendisi için gerekli eserleri belirleyememekte bu durum zaman ve enerji verimsizliğine yol açmaktadır. Yapılan taramalar sonucunda alanın literatürünü genel itibari ile ve nesnel biçimde değerlendiren bir çalışmaya rastlanılamamıştır. Bu çalışma tam bu noktada okuyucuların konu hakkında araştırma yaparken başvurabilecekleri, bir kaynaktır. Alan hakkında okuma yapılırken takip edilmesi gereken yazarlar, ülkeler ve kaynaklar çalışmada detaylıca yer almaktadır. Akademik araştırmalarda bu çalışmanın dikkatlice incelenmesi ve sonrasında gerekli okumaların yapılması araştırmacıların zamanını tasarruflu kullanmalarını sağlayacaktır. Bununla birlikte sağlık sektöründe gerçekleştirilmesi planlanan yatırımlarda, sağlık teknolojilerinin değerlendirilmesinde, kritik öneme sahip kararların alınmasında ve politika oluşturulmasında yine çalışmanın incelenmesinde büyük fayda vardır. Çünkü bu durumlarda fon sağlama ve kaynak aktarma gibi durumlarda konu ile alakalı esas kurum ve kuruluşları belirleme sürece katkı sağlanacaktır. Konu ile alakalı en çok makale yayınlayan dergi IEEE Access Dergisi'dir ve dergi en yüksek h ve $g$ indeksine sahiptir. En yüksek m indeksine sahip dergi ise Future Generation Computer Systems-The International Journal of Escience Dergisi'dir. Bu dergilerde yayınlanan çalışmaların atıf sayısının yüksek olduğu görülmüştür. Fakat dergilerin makale sayılarının Bradford Yasası'na uygun şekilde dağılmadığı sonucuna ulaşılmıştır. 5 çekirdek dergide yayınlanan makaleler analizde yer alan tüm makalelerin \%33,52'sini oluşturmaktadır. Konu ile en alakalı yazarın Sood SK olduğu görülmektedir ve yazarın alana katkı sağlayan 11 adet makalesi bulunmaktadır. Alandaki yazar dağılımı incelendiğinde dağılımın Lotka Yasası'na uymadığı görülmektedir. En üretken ülke sıralaması Çin, Amerika Birleşik Devletleri ve Hindistan şeklindedir. En çok alıntı yapılan doküman Islam SMR'nin 2015 yılında yazmış olduğu IEEE Access'te yayınlanan çalışmasıdır. Makalelerin özet kısımlarında data kelimesinin $1167 \mathrm{kez}$, anahtar kelimeler kısmında internet of things kelime grubunun $135 \mathrm{kez}$, kaynakça kısımlarında internet kelimesinin 157 kez ve başlık kısımlarında healthcare kelimesinin 236 kez kullanıldığ yer alan konu Internet of Things, başlıklarda healthcare, özetlerde data, keyword plus kısmında internettir. Ayrıca kelime analizine göre en az 10 kez kullanılan kelimeler 4 küme oluşturmaktadır. Kümelerdeki kelimelerin araştırma alanlarının incelenmesi, hareket sinyallerinin doğruluğu, protokol gizliliği, verimliliği ve güvenliği ile iletişim teknolojilerindeki gelişmeler başlıkları altında oluşum gösterdikleri görülmüştür.

Çalışmadaki en büyük sınırlılık veri tabanı olarak yalnızca Web of Science Core Collection veri tabanının kullanılmasıdır. Veri tabanından yalnızca İngilizce dilinde yazılan, makale ve review formatında olan çalışmalar indirilmiştir. Bununla birlikte veri tabanında yer alan ilk çalışmanın 2001 yılında yayınlandığ görülmüştür ve çalışmalar bu tarihten itibaren analiz edilmiştir. $\mathrm{Bu}$ tarihten öncesinde yayınlanan çalışma var ise analize dahil edilmemiştir. Benzer bir biçimde atıf analizlerinde yalnızca bu veri tabanında yer alan kayıtlar değerlendirilmiştir. Çalışmada bibliyometrik analizden kaynaklanan sinırlılıklar da bulunmaktadır. Görselleştirme programı olan $\mathrm{R}$ 4.0.3 paket programının izin verdiği ölçüde veriler görselleştirilmiş olup programın hata verdiği analizlerden çıktı alınamamıştır. Ayrıca bu çalışmaya özgü olarak paket programın isim ve soyisim benzerliği olan üç yazarı aynı yazarmış gibi kodlayarak analizlere tabi tuttuğu gözlemlenmiş̧tir. $\mathrm{Bu}$ durumun yazarlara ait bazı analizlerde hatalı sonuçlar alınmasına sebep olduğu görülmüştür. Söz konusu bu kısıtlama bu çalışmaya özgü olsa da her çalışmada ortaya çıkabilecek bir durum olduğu göz önünde bulundurulmalıdır.

\section{Kaynakça}

Abawajy, J. H., \& Hassan, M. M. (2017). Federated Internet of Things and cloud computing pervasive patient health monitoring system. IEEE Communications Magazine, 55(1), $48-53$.

Akhbarifar, S., Javadi, H. H. S., Rahmani, A. M., \& Hosseinzadeh, M. (2020). A secure remote health monitoring model for early disease diagnosis in cloud-based IoT environment. Personal and Ubiquitous Computing, 1-17. https://doi.org/10.1007/s00779-020-01475-3

Al-Fuqaha, A., Guizani, M., Mohammadi, M., Aledhari, M., \& Ayyash, M. (2015). Internet of Things: A survey on enabling technologies, protocols and applications. IEEE Communications Surveys And Tutorials, 17(4), 2347-2376.

Albahri, O. S., Albahri, A. S., Zaidan, A. A., Zaidan, B. B., Alsalem, M. A., Mohsin, A. H., ... \& Shareef, A. H. (2019). Fault-tolerant mHealth framework in the context of IoT-based real-time wearable health data sensors. IEEE Access, 7, 50052-50080.

Alhasan, A., Audah, L., Ibrahim, I., Al-Sharaa, A., Al-Ogaili, A. S., \& Mohammed, J. M. (2020). A case-study to examine doctors' intentions to use IoT healthcare devices in Iraq during COVID-19 pandemic. International Journal of Pervasive Computing and Communications. https://doi.org/https://doi.org/10.1108/IJPCC-10-2020-0175

Alhussein, M., Muhammad, G., Hossain, M. S., \& Amin, S. U. (2018). Cognitive IoT-Cloud integration for smart healthcare: Case study for epileptic seizure detection and monitoring. Mobile Networks and Applications volume, 23, 1624-1635.

Amendola, S., Lodato, R., Manzari, S., Occhiuzzi, C., \& Marrocco, G. (2014). RFID technology for IOT-based personel healthcare in smart spaces. IEEE Internet of Things Journal, 1(2), 144-152.

Amin, S. U., Hossain, M. S., Muhammed, G., Alhussein, M., \& Rahman, M. A. (2019). Cognitive smart healthcare for pathology detection and monitoring. IEEE Access, 7, 1074510753. https://doi.org/10.1109/ACCESS.2019.2891390

Aria M, Cuccurullo C. (2017), bibliometrix: An R-tool for comprehensive science mapping analysis. Journal of informetrics;11(4):959-75

Asghari, P., Rahmani, A. M., \& Javadi, H. H. S. (2019). Internet Of Things application: A systematic review. Computer Networks, 148, 241-261.

Baker, S. B., Xiang, W., \& Atkinson, I. (2017). Internet of Things for smart healthcare: Technologies, challenges and opportunities. IEEE Access, 5, 26521-26544.

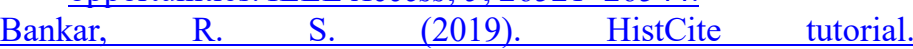
http://eprints.rclis.org/41954/1/Document1.pdf.

Barata, J. J. R., Munoz, R., De Carvalho Silva, R. D., Rodrigues, J., \& Albuquerque, V. H. (2019). Internet of Things based on 
electronic and mobile health systems for blood glucose continuous monitoring and management. IEEE Access, 7 , 175116-175125.

https://doi.org/10.1109/ACCESS.2019.2956745

Bastian, M., Heymann, S., ve Jacomy, M. (2009, March). Gephi: an open source software for exploring and manipulating networks. In Third international AAAI conference on weblogs and social media.

Bhatt, Y., \& Bhatt, C. (2017). Internet of Things in HealthCare. Icinde Internet of Things and Big Data Technologies for Next Generation Healthcare (ss. 13-33). Cham, Switzerland: Springer International Publishing AG.

Bornmann, L., \& Daniel, H. D. (2007). What do we know about the $\mathrm{h}$ index? Journal of the American Society for Information Science and Technology, 58(9), 1381-1385.

Bouzembrak, Y., Klüche, M., Gavai, A., \& Marvin, H. J. P. (2019). Internet of Things in food safety: Literature review and a bibliometric analysis. Trends in Food Science \& Technology, 94, 54-64.

Castillejo, P., Martinez, J.-F., Rodriguez Molina, J., \& Cuerva, A. (2013). Integration of wearable devices in a wireless sensor network for an e-health application. IEEE Wireless Communications, 20(4). https://doi.org/10.1109/MWC.2013.6590049

Catarinucci, L., De Donno, D., Mainetti, L., Palano, L., Patrono, L., Stefanizzi, M. L., \& Tarricone, L. (2015). An IoT-Aware architecture for smart healthcare systems. IEEE Internet of Things Journal, 2(6), 515-526. https://doi.org/10.1109/JIOT.2015.2417684

Chen, C. (2014). The citespace manual. College of Computing and Informatics, 1, 1-84

Chen, M., Ma, Y., Li, Y., Wu, D., Zhang, Y., \& Youn, C. H. (2017). Wearable 2.0: Enabling human-cloud integration in next generation healthcare systems. IEEE Communications Magazine, 55(1), 54-61. https://doi.org/10.1109/MCOM.2017.1600410CM

Cobo, M. J., López-Herrera, A. G., Herrera-Viedma, E., \& Herrera, F. (2012). SciMAT: A new science mapping analysis software tool. Journal of the American Society for Information Science and Technology, 63(8), 1609-1630.

Dadkhah, M., Lagzian, M., Rahimnia, F., \& Kimiafar, K. (2020). What do publications say about the Internet of Things challenges/barriers to unnformed authors? A bibliometric analysis. JLIS.it, 11(3), 77-98. https://doi.org/10.4403/jlis.it12634

Darwish, A., Hassanien, A. E., Elhoseny, M., Sangaiah, A. K., \& Muhammmad, K. (2019). The impact of the hybrid platform of internet of things and cloud computing on healthcare systems: opportunities, challenges, and open problems. Journal of Ambient Intelligence and Humanized Computing, 10 , 4151-4166. https://doi.org/https://doi.org/10.1007/s12652-017-0659-1

Dimitrov, D. (2016). Medical Internet of Things and Big Data in Healthcare. Healthcare Informatics Research, 22(3), 156163.

Egghe, L. (2006). Theory and practise of the g-index. Scientometrics, 69(1), 131-152.

Elhoseny, M., Abdelaziz, A., Salama, A. S., Riad, A. M., Muhammad, K., \& Sangaiah, A. K. (2018). A hybrid model of Internet of Things and cloud computing to manage big data in health services applications. Future Generation Computer Systems, $86, \quad 1383-1394$. https://doi.org/https://doi.org/10.1016/j.future.2018.03.005
European Environment Agency. (2020). R Core Team (2020). Tarihinde 06 Aralı 2020, adresinden erișildi https://www.eea.europa.eu/data-andmaps/indicators/oxygen-consuming-substances-in-rivers/rdevelopment-core-team-2006

Griggs, K. N., Ossipova, O., Kohlios, C. P., Baccarini, A. N., Howson, E. A., \& Thaier, H. (2018). Healthcare blockchain system using smart contracts for secure automated remote patient monitoring. Journal of Medical Systems, 42, 130. https://doi.org/10.1007/s10916-018-0982-X.

Harzing, A. W. (2012). Reflections on the h-index. Business\&Leadership, 1(9), 101-106.

Hirsch, J. E. (2007). Does the $\mathrm{h}$ index have predictive power? PNAS, 104(49), 19193-19198.

Hossain, M. S., \& Muhammad, G. (2016). Cloud-assisted Industrial Internet of Things (IIoT) - Enabled framework for health monitoring. Computer Networks, 101, 192-202. https://doi.org/https://doi.org/10.1016/j.comnet.2016.01.009

Hossain, M. S., \& Muhammad, G. (2017). Emotion-aware connected healthcare big data towards 5G. IEEE Internet of Things Journal, 5(4), 2399-2406. https://doi.org/10.1109/JIOT.2017.2772959

IEEE Access. (2020). Learn More About IEEE Access. Tarihinde 22 Kasim 2020, adresinden erișildi https://ieeeaccess.ieee.org/about-ieee-access/learn-moreabout-ieee-access/

Islam, S. M. R., Kwak, D., Kabir, M. H., Hossain, M., \& Kwak, K.-S. (2015). The Internet of Things for health care: A comprehensive survey. IEEE Access, 3, 678-708. https://doi.org/10.1109/ACCESS.2015.2437951

Kaba, A., \& Ramaiah, C. K. (2019). Bibliometric Analysis of Research Output on the Internet of Things in the Arab World. DESIDOC Journal of Library \& Information Technology, 39(5).

Kelly, J. T., Campbell, K. L., \& Scuffham, P. (2020). The Internet of Things: Impact and implications for health care delivery. Journal of Medical Internet Research, 22(11). https://doi.org/10.2196/20135

Konstantinidis, S., Billis, A., Wharrad, H., \& Bamidis, P. D. (2017). Internet of Things in Health Trends Through Bibliometrics and Text Mining. In Informatics for Health: Connected Citizen-Led Wellness and Population Health. , (73-77). https://doi.org/10.3233/978-1-61499-753-5-73

Kumar Dwivedi, R., Kumar, R., \& Buyya, R. (2021). Gaussian Distribution-based machine learning for anomaly detection in healthcare sensor cloud. International Journal of Cloud Applications and Computing (IJCAC), 11(1), 52-72.

Kumar, P., Kumari, S., Sangaiah, A. K., Wei, J., \& Li, X. (2018). A certificateless aggregate signature scheme for healthcare wireless sensor network. Sustainable Computing: Informatics \begin{tabular}{lll}
\hline and $\quad$ Systems, & 80-89.
\end{tabular} https://doi.org/http://dx.doi.org/10.1016/j.suscom.2017.09.0 $\underline{02}$

Kumar, P. M., Lokesh, S., Varatharajan, R., Babu, G. C., \& Parthasarathy, P. (2018). Cloud and IoT based disease prediction and diagnosis system for healthcare using Fuzzy neural classifier. Future Generation Computer Systems, $\underline{86(527-534) \text {. }}$

https://doi.org/https://doi.org/10.1016/j.future.2018.04.036

Kurutkan, M. N., ve Orhan, F. (2018a). Kalite Prensiplerinin Görsel Haritalama Tekniğine Göre Bibliyometrik Analizi. SAGE Yayıncılik San. Tic. ve Ltd. Sti, 1, 7-14.

Kurutkan, M. N., ve Orhan, F. (2018b). Sağlık Politikas1 
$\underline{\text { Konusunun Bilim Haritalama Teknikleri ile Analizi. İKSAD }}$ Publications, 1-12.

Leong, Y. R., Tajudeen, F. P., \& Yeong, W. C. (2021). Bibliometric and content analysis of the internet of things research: a social science perspective. Online Information Review.

Li, G., Xu, G., Sangaiah, A. K., Wu, J., \& Li, J. (2019). EdgeLaaS: Edge Learning as a Service for Knowledge-Centric Connected Healthcare. IEEE, 33(6), 37-43. https://doi.org/10.1109/MNET.001.1900019

Li, X., Pak, C., \& Bi, K. (2020). Analysis of the development trends and innovation characteristics of Internet of Things technology-based on patentometrics and bibliometrics. Technology Analysis \& Strategic Management, 32(1), 104118.

Lotka, A. J. (1926). The frequency distribution of scientific productivity. Journal of the Washington Academy of Sciences, 16(12), 317-323.

MA, Y., Wang, Y., Yang, J., Miao, Y., \& Li, W. (2016). Big Health Application System based on Health Internet of Things and Big Data. IEEE Access, 5, 7885-7897. https://doi.org/10.1109/ACCESS.2016.2638449

Madjido, M., Espressivo, A., Maula, A. W., Fuad, A., \& Hasanbasri, M. (2019). Health information system research situation in Indonesia: A bibliometric analysis. Procedia Computer Science, 161, 781-787. https://doi.org/https://doi.org/10.1016/j.procs.2019.11.183

Mahmoud, M. M. E., Rodrigues, J., Ahmed, S. H., Shah, S. C., Al Muhtadi, J., Korotaev, V., \& Albuquerque, V. H. (2018). Enabling technologies on Cloud of Things for Smart Healthcare. IEEE Access, 6, 31950-31967. https://doi.org/10.1109/ACCESS.2018.2845399

Mahmoud, M. M. E., Rodrigues, J., Saleem, K., Al Muhtadi, J., \& Korotaev, V. (2018). Towards energy-aware fog-enabled cloud of things for healthcare. Computers and Electrical Engineering, 67, 58-69.

Mano, L. Y., Faiçal, B. S., Nakamura, L. H. V, Gomes, P. H., Libralon, G. L., Meneguete, R. I., ... Ueyama, J. (2016). Exploiting IoT technologies for enhancing Health Smart Homes through patient identification and emotion recognition. Computer Communications, 89(90), 178-190. https://doi.org/https://doi.org/10.1016/j.comcom.2016.03.01 $\underline{0}$

Manyika, J., Michael, C., Bughin, J., Dobbs, R., Bisson, P., \& Marrs, A. (2013). Disruptive technologies: Advances that will transform life, business, and the global economy. San Francisco, CA, USA.

MDPI. (2020). Sensors. Tarihinde 22 Kasim 2020, adresinden erișildi https://www.mdpi.com/journal/sensors

Mishra, D., Gunasekaran, A., Childe, S. J., Papadopoulos, T., Dubey, R., \& Wamba, S. (2016). Vision, applications and future challenges of Internet of Things: A bibliometric study of the recent literature. Industrial Management \& Data Systems.

Miskiewicz, R. Internet of Things in Marketing Bibliometric Analysis (2020). Marketıng and Management Of Innovations. 2020, 3, 371-381.

Nepal, S., Ranjan, R., \& Choo, K.-K. R. (2015). Trustworthy processing of healthcare big data in hybrid clouds. IEEE $\begin{array}{lll}\text { Cloud Compiting, 2(2), 78-84. } & \end{array}$ https://doi.org/10.1109/MCC.2015.36

Ngayua, E. N., He, J., \& Boahene, K. A. (2020). Applying advanced technologies to improve clinical trials: a systematic mapping study. Scientometrics, 21, 1-22. https://doi.org/10.1007/s11192-020-03774-1

Nobre, G. C., \& Tavares, E. (2017). Scientific literature analysis on big data and internet of things applications on circular economy: a bibliometric study. Scientometrics, 111(1), 463492.

Pai, R. R., \& Alathur, S. (2021). Bibliometric Analysis and Methodological Review of Mobile Health Services and Applications in India. International Journal of Medical Informatics, $145, \quad 104330$. https://doi.org/https://doi.org/10.1016/j.ijmedinf.2020.10433 $\underline{0}$

Pang, Z., Zheng, L., Tian, J., Kao-Walter, S., Dubrova, E., \& Chen, Q. (2015). Design of a terminal solution for integration of in-home health care devices and services towards the Internet-of-Things. Enterprise Information Systems, 9(1), $\underline{86-116 .}$

Pernitez-Agan, S., Bautistia, M. A., Lopez, J., Sampson, M., \& Wickramage, K. (2020). Bibliometric analysis of Covid-19 in the context migration health: A study protocol. medRxiv, 110 . https://doi.org/https://doi.org/10.1101/2020.07.09.20149401

Persson, O., Danell, R., ve Schneider, J. W. (2009). How to use Bibexcel for various types of bibliometric analysis. Celebrating scholarly communication studies: A Festschrift for Olle Persson at his 60th Birthday, 5, 9-24.

Potter, W. . (1988). Of making many books there is no end': bibliometrics and libraries. Journal of Academic Librarianship, 14(4), 238a-9c.

Prajapati, V. (2013). Big Data Analytics with R and Hadoop. UK: Packt Publishing.

Princi, E., \& Kramer, N. (2020). Out of control-privacy calculus and the effect of perceived control and moral considerations on the usage of IoT healthcare devices. Frontiers in Psychology, 11. https://doi.org/10.3389/fpsyg.2020.582054

Purandhar, N., Ayyasamy, S., \& Saravanakumar, N. . (2020). Clustering healthcare big data using advanced and enhanced fuzzy C-means algorithm. International Journal of Communication Systems, 34(1). https://doi.org/https://doi.org/10.1002/dac.4629

Qi, J., Yang, P., Waraich, A., Deng, Z., Zhao, Y., \& Yang, Y. (2018). Examining sensor-based physical activity recognition and monitoring for healthcare using Internet of Things: A systematic review. Journal of Biomedical Informatics, 87, 138-153. https://doi.org/https://doi.org/10.1016/j.jbi.2018.09.002

Rahmani, A. M., Gia, T. N., Negash, B., Anzanpour, A., Azimi, I., Jiang, M., \& Liljeberg, P. (2018). Exploiting smart e-Health gateways at the edge of healthcare Internet-of-Things:A fog computing approach. Future Generation Computer SystemsThe International Journal of Escience, 78(2), 641-658.

Rawashdeh, M., Mohammed, G. A. Z., Hossain, M. S., Samarah, S., Amin, S. U., \& Muhammad, G. (2018). Reliable service delivery in Tele-health care systems. Journal of Network and Computer Applications, 115. https://doi.org/10.1016/j.jnca.2018.04.015

Rodrigues, JJPC Segundo, D., Junqueira, H., Sabino, M., Prince, R., Al-Muhtadi, J., \& Albuquerque, D. (2018). Enabling Technologies for the Internet of Health Things. IEEE Access, $\underline{6}$ https://doi.org/10.1109/ACCESS.2017.2789329

Rodriquez-Soler, R., Uribe-Toril, J., \& Valencio, J. D. P. (2020). Worldwide trends in the scientific production on rural depopulation, a bibliometric analysis using bibliometrix R- 
tool. Land Use Policy, 97, 104787.

Roehrs, A., da Costa, C. A., Righi, R. da R., \& Farias de Oliveira, $\underline{\text { K. S. (2017). Personal health records: A systematic literature }}$ review. Journal of Medical Internet Research, 19(1). https://doi.org/10.2196/jmir.5876

Rowlands, I. (2004). Emerald authorship data, Lotka's law and research productivity. Emerald Insight, 57(1), 5-10.

Sadoughi, F., Behmanesh, A., \& Sayfouri, N. (2020). Internet of things in medicine: A systematic mapping study. Journal of Biomedical Informatics, $103, \quad 103383$. https://doi.org/https://doi.org/10.1016/j.jbi.2020.103383

Santos, J., Rodrigues, J., Silva, B. M., Casal, J., Saleem, K., \& Denisov, V. (2016a). An Iot-based mobile gateway for intelligent personal assistans on mobile health environments. Journal of Network and Computer Applications. https://doi.org/http://dx.doi.org/10.1016/j.jnca.2016.03.014

Santos, J., Rodrigues, J., Silva, B. M., Casal, J., Saleem, K., \& Denisov, V. (2016b). An IoT-based mobile gateway for intelligent personal assistants on mobile health environments. Journal of Network and Computer Applications, 71. https://doi.org/10.1016/j.jnca.2016.03.014

Shang, G., Saladin, B., Fry, T., \& Donohue, J. (2015). Twenty-six years of operations management research (1985-2010): authorship patterns and research constituents in eleven top rated journals. International Journal of Production Research, 53(20), 6161-6197.

Sodhro, A. H., Pirbhulal, S., \& Sangaiah, A. K. (2018). Convergence of IoT and product lifecycle management in medical health care. Future Generation Computer Systems, $\underline{86,380-391 .}$

https://doi.org/https://doi.org/10.1016/j.future.2018.03.052

Suciu, G., Martian, A., Craciunescu, R., Vulpe, A., Marcu, I., Halunga, S., \& Fratu, O. (2015). Big data, Internet of Things and Clous Convergence-An architecture for secure e-health applications. Journal of Medical Systems, 39(11), 327. https://doi.org/10.1007/s10916-015-0327-y

Talal, M., Zaidan, A. ., Zaidan, B. ., Albahri, A. ., Alamoodi, A. ., Albahri, O. .. ... Mohammed, K. . (2019). Smart Home-based IoT for real-time and secure remote health monitoring of triage and priority system using body sensors: Multi-driven systematic review. Journal of Medical Systems, 43(42), 1-34. https://doi.org/https://doi.org/10.1007/s10916-019-1158-z

The R Foundation. (2020). What is R? Tarihinde 06 Aralık 2020, adresinden erișildi https://www.r-project.org/about.html

Tian, S., Yang, W., Grange, J. M. Le, Wang, P., Huang, W., \& Ye, Z. (2019). Smart healthcare: making medical care more intelligent. Global Health Journal, 3(3), 62-65. https://doi.org/10.1016/j.glohj.2019.07.001

Tsai, J. C., Leu, J.-S., Prakosa, S. W., Hsiao, L.-C., Huang, P.-C., Yang, S.-Y., \& Huang, Y.-T. (2020). Design and implementation of an Internet of Healthcare Things System for respiratory diseases. Wireless Personal Communications, 1-14. https://doi.org/10.1007/s11277-020-07871-5

Uslu, Calıs, B., Okay, E., \& Dursun, E. (2020). Analysis of factors affecting IoT-based smart hospital design. J Cloud Comp, 9(1). https://doi.org/10.1186/s13677-020-00215-5

Van Eck, N. J., ve Waltman, L. (2013). VOSviewer manual. Leiden: Univeristeit Leiden, 1(1), 1-53

Vilela, P. H., Rodrigues, J., Solic, P., Saleem, K., \& Furtado, V. (2019). Performance evaluation of a fog-assisted IoT solution for e-Health applications. Future Generation Computer Systems, 97, 379-386.

Wu, F., Li, X., Sangaiah, A. K., Xu, L., Kumari, S., Wu, L., \&
Shen, J. (2018). A lightweight and robust two-factor authentication scheme for personalized healthcare systems using wireless medical sensor networks. Future Generation \begin{tabular}{llll}
\hline Computer & Systems, & 82, & $727-737$.
\end{tabular} https://doi.org/https://doi.org/10.1016/j.future.2017.08.042

Xiang, G. Y., Zeng, Z., \& Shen, Y. J. (2016). Present Situation and Development Trend of China's Intelligent Medical Construction. Chinese General Practice, 19(24), 2998-3000. https://doi.org/10.3969/j.issn.1007-9572.2016.24.027

Xie, C., Cai, H., Yang, Y., Jiang, L., \& Yang, P. (2018). User profiling in elderly healthcare services in China: Scalper Detection. IEEE Journal of Biomedical and Health Informatics, 22(6), 1796-1806. https://doi.org/10.1109/JBHI.2018.2852495

Yang, P., Qi, J., Min, G., \& Xu, L. (2017). Advanced Internet of Things for personalised healthcare system: A survey. Pervasive and Mobile Computing, 41, 132-149.

Yang, P., Stankevicius, D., Marozas, V., Deng, Z., Liu, E., Lukosevicius, A., ... Min, G. (2018). Lifelogging data validation model for Internet of Things enabled personalized healthcare. IEEE Transactions on Systems, Man, and Cybernetics: Systems, 48(1), 50-64.

Yang, Yang, Zheng, X., Guo, W., Liu, X., \& Chang, V. (2019). Privacy-preserving smart IoT-based healthcare big data storage and self-adaptive access control system. Information Sciences, 479, 567-592.

Yang, Yun, Nan, F., Yang, P., Meng, Q., Xie, Y., Zhang, D., \& Muhammad, K. (2019). GAN-Based Semi- Supervised learning approach for clinical decision support in health-IoT \begin{tabular}{lllll}
\hline platform. IEEE Access, & 7, & $8048-8057$.
\end{tabular} https://doi.org/10.1109/ACCESS.2018.2888816

Yin, Y., Zeng, Y., Chen, X., \& Fan, Y. (2016). The internet of things in healthcare: An overview. Journal of Industrial Information Integration, 1, 3-13.

Zhang, D., Xia, X., Yang, Y., Yang, P., Xie, C., Cui, M., \& Liu, Q. (2021). A novel word similarity measure method for IoTenabled healthcare applications. Future Generation \begin{tabular}{llll}
\hline Computer & Systems, & 209-218.
\end{tabular} https://doi.org/https://doi.org/10.1016/j.future.2020.07.053

Zupic, I., \& Cater, T. (2014). Bibliometric methods in management and organization. Organizational Research Methods, 18(3), 429-472. 